\title{
HORSE-RACING IN NINETEENTH-CENTURY RUSSIA
}

\section{SIMON DIXON}

IN 1946, Stalin presented the departing American ambassador, W. Averell Harriman, with two thoroughbreds he had admired from a newsreel of the Soviet victory parade on Red Square. The horses sailed to New York under the care of a Russian vet, a jockey and two grooms. ${ }^{1}$ Though Harriman was a renowned breeder and racer, Stalin's gift belonged in a tradition of European diplomatic gestures reaching back beyond the Renaissance. And diplomacy formed only part of a broader equestrian culture encompassing the entire spectrum of symbolic and material relationships between man and horse. ${ }^{2}$ Economic historians who set out to explore the grittier side of these relationships in the 1970s were conscious of seeming mildly eccentric. ${ }^{3}$ Reviewers did little to disabuse them. At that stage, sceptics accustomed to hard-nosed talk of take-off and growth predicted that any renewed interest in equine matters was more likely to stimulate an enhanced awareness of the horse's role among specialists in military, agricultural or transport history than to generate a self-standing literature. ${ }^{4}$ Since

Simon Dixon is Sir Bernard Pares Professor of Russian History at UCL SSEES.

Tim Blanning, Sergei Bogatyrev, R.J.W. Evans, Jennifer Keating, Diane P. Koenker, Tom Marsden, Dominic Lieven, Martyn Rady and Hamish Scott generously helped to improve this article. So did two anonymous readers for SEER. Unless otherwise indicated, dates for Russian sources follow the Julian calendar, eleven days behind the Western Gregorian calendar in the eighteenth century and twelve days behind in the nineteenth.

${ }^{1}$ Tim Tzouliadis, The Forsaken: From the Great Depression to the Gulags, London, 2008, p. 247 and plate.

2 Daniel Roche, 'Equestrian Culture in France from the Sixteenth to the Nineteenth Century', Past and Present, 199, May 2008, pp. 113-45, is merely a taster for the equally francocentric Roche, La culture équestre occidentale, XVI ${ }^{e}$-XIX siècle: l'ombre du cheval, 3 vols, Paris, 2008-15.

3 The pioneer was F.M.L. Thompson, 'Nineteenth-Century Horse Sense', Economic History Review, 29, 1976, 1, pp. 60-81; Thompson (ed.), Horses in European Economic History: A Preliminary Canter, Reading, 1983.

${ }^{4}$ For example, E.L. Jones in Economic History Review, 37, 1984, 2, pp. 295-96. As a global historian avant la lettre, Jones also sensed the limits of a Eurocentric perspective. See now Peter Mitchell, Horse Nations: The Worldwide Impact of the Horse on Indigenous Societies Post-1492, Oxford, 2014. 
then, however, the 'cultural turn' has helped to foster a growing body of work seeking not only to trace the animal's myriad functions from warhorse to workhorse, but to map the ways in which they were constructed in a multitude of different minds. In this literature, the image of the racehorse has remained largely unchanged, as a marker of social status and as a symbol of conspicuous consumption on the part of profligate elites. ${ }^{5}$

A key aim of the new animal-centred scholarship has been to restore the visibility of the horse to places from which it might have been expected to disappear. Since these included even the world's most advanced industrial economies, ${ }^{6}$ it is odd that we still lack an integrated approach focused on Russia, where horses were more numerous than anywhere else, and where their military and socioeconomic significance persisted until at least the Second World War. ${ }^{7}$ Only Muscovite equestrian culture has been systematically investigated. ${ }^{8}$ Otherwise, the picture remains fragmentary in much the way anticipated by sceptics in the 1970s. Penetrating analyses of estate management, horse theft and the postal system hint at the scope offered by the imperial era. ${ }^{9}$ Horses naturally feature in studies of

\footnotetext{
${ }^{5}$ See, inter alia, Karen Raber and Treva J. Tucker (eds), The Culture of the Horse: Status, Discipline and Identity in the Early Modern World, New York, 2005; Tatsuya Mitsuda, 'The Horse in European History, 1550-1900', Univ. of Cambridge Ph.D. thesis, 2007; Peter Edwards, Horse and Man in Early Modern England, London, 2007; Peter Edwards, Karl A.E. Enenkel and Elspeth Graham (eds), The Horse as Cultural Icon: The Real and the Symbolic Horse in the Early Modern World, Leiden, 2012; Ulrich Raulff, Farewell to the Horse: The Final Century of Our Relationship, trans. R.A. Kemp, London, 2017. ${ }^{6}$ Ann Norton Greene, Horses at Work: Harnessing Power in Industrial America, Cambridge, MA, 2008, ranges much wider than its title implies.

${ }^{7}$ According to Sheila Fitzpatrick, Stalin's Peasants: Resistance and Survival in the Russian Village after Collectivization, Oxford, 1994, pp. 135-36, horses 'became even more important in socioeconomic terms in the 1930s than they had been before'.

${ }^{8}$ Ann M. Kleimola, 'Good Breeding, Muscovite Style: "Horse Culture" in Early Modern Rus', Forschungen zur osteuropäischen Geschichte, 50, 1995, pp. 199-238; Kleimola, 'Cultural Convergence: The Equine Connection between Muscovy and Europe', in Raber and Tucker (eds), Culture of the Horse, pp. 45-62.

${ }^{9}$ Olga Crisp, 'Horses and Management of a Large Agricultural Estate in Russia at the End of the Nineteenth Century', in Thompson (ed.), Horses in European Economic History, pp. 15676; Christine Worobec, 'Horse Thieves and Peasant Justice in Post-Emancipation Imperial Russia', Journal of Social History, 21, 1987, 2, pp. 281-93; John Randolph, 'Communication and Obligations: The Postal System of the Russian Empire, 1700-1850', in Simon Franklin
} 
legislation against cruelty to animals. ${ }^{10}$ And there is suggestive evidence of the importance of horses and riding for male bonding in provincial noble families. ${ }^{11}$ Racing, however, has been all but ignored. Whereas nineteenth-century American racecourses have been explored as sites for the development of racial and political identities, ${ }^{12}$ historians of Russia remain faithful to the trail blazed by Wray Vamplew, whose classic study of the English turf established horse-racing's place in the history of leisure. ${ }^{13}$ Louise McReynolds' spirited account of the era of mass entertainment places the transformative moment in Russia in 1876 with the advent of the totalizator. Not only did legalized mass betting underpin racing's emergence as Russia's first national sport. It also allegedly relieved the government of the expense of breeding thoroughbreds for the army: 'It would take the tsar who freed the serfs, Alexander II, to liberate the state from the stables. Pressed to pay for the emancipation during an economic depression, he quite frankly needed the money'. ${ }^{14}$

Like many rhetorical triumphs, this one comes at considerable analytical cost. While the introduction of mass betting undoubtedly transformed the sport's finances, many premodern features of horse-racing survived after 1900 when owners continued to bear ruinous

and Katherine Bowers (eds), Information and Empire: Mechanisms of Communication in Russia, 1600-1854, Cambridge, 2017, pp. 155-83.

${ }^{10}$ Amy Nelson, 'The Body of the Beast: Animal Protection and Anticruelty Legislation in Imperial Russia', in Jane Costlow and Amy Nelson (eds), Other Animals: Beyond the Human in Russian Culture and History, Pittsburgh, 2010, pp. 95-112.

${ }^{11}$ Compare Katherine Pickering Antonova, An Ordinary Marriage: The World of a Gentry Family in Provincial Russia, Oxford and New York, 2013, p. 170, with Monica Mattfeld, Becoming Centaur: Eighteenth-Century Masculinity and English Horsemanship, Philadelphia, 2017.

${ }^{12}$ Katherine C. Mooney, Race Horse Men: How Slavery and Freedom were made at the Racetrack, Cambridge, Mass., 2014.

${ }^{13}$ In fact, as its subtitle implies, Wray Vamplew, The Turf: A Social and Economic History of Horse Racing, London, 1976, reaches far beyond the racecourse. Rebecca Cassidy (ed.), The Cambridge Companion to Horseracing, Cambridge, 2013, reflects subsequent anglophone approaches. For a continental perspective, see Nicole de Blomac, La Gloire et le jeu: des hommes et des chevaux (1766-1866), Paris, 1991.

${ }^{14}$ Louise McReynolds, Russia at Play: Leisure Activities at the End of the Tsarist Era, Ithaca, 2003, p. 79. 
expense in pursuit of pleasure, prestige and the elusive perfect breed. Glancing back to the aristocratic origins of Russian horse-racing in the 1780s and forward to the age of mass entertainment, this article focuses on little-known developments between 1825 and 1875 . It argues that the sport's crucial dynamic was a lasting tension between proponents of the English thoroughbred (which the army required only for cavalry guards officers' riding horses) and advocates of less fragile, less temperamental breeds, notably the Orlov trotter. ${ }^{15}$ The pivotal period was the 1840s, when the English model introduced to Russia under Catherine II came under sustained attack, and when harness-racing and peasant cart-racing, both of which reached a wider public than flat-racing or steeplechasing, first flourished under the umbrella of the Ministry of State Domains. It will be argued that state support for private owners amounted to incentives rather than subsidies; that their withdrawal in the $1860 \mathrm{~s}$ affected racing less than wider changes in the economy and culture of the nobility; and that though government spending was subsequently reduced, it was never abandoned.

Racing, in other words, not only offers a productive way into thinking about broader relationships within Russian equestrian culture but is itself incomprehensible without some preliminary consideration of those relationships. In particular, since the underlying purpose of racing was to test and promote the development of breeds capable of an ideal combination of speed, strength and endurance, the histories of breeding and racing in Russia are just as intimately linked as they were elsewhere, and the breeders' journal, published monthly from January 1842, contains the single most comprehensive record of race meetings both at home and abroad. ${ }^{16}$ Nineteenth-century horse-breeders found themselves trapped between

\footnotetext{
${ }^{15}$ Russia therefore merits a more prominent place in the networks and debates sketched by Mike Huggins, 'Cultural transfer, circulation, and diffusion between Britain and Europe from the 1770s to the 1870s: The Case of Thoroughbred Horse-Racing and Breeding', The International Journal of the History of Sport, 36, 2019, 17-18, pp. 1510-1530.

${ }^{16}$ Best accessed through I.V. Dmitrovskii, Bibliograficheskii ukazatel' $k$ 'Zhurnalu konnozavodstva' za 1842-1891 gg., 2 vols, St Petersburg, 1892-93.
} 
competing interests, ranging from military procurement (warhorse) to the demands of an overwhelmingly agricultural economy (workhorse). Each represents a vast subject in its own right, parallel partly to the distinction between konnozavodstvo (the cultivation of pedigree bloodstock in the quest for the perfect breed), the focus of this article, and konezavodstvo (a more widespread branch of animal husbandry designed to reproduce horses for particular purposes, especially peasant farming). But I begin by outlining the changing ways in which the state tried to regulate the balance between the two, labouring throughout under the constraints of a wider economic context in which the supply of all but the most exceptional horses consistently outstripped demand.

\section{Racing, breeding and the state}

It was hard for anyone to make money from horse-breeding in nineteenth-century Russia. Territorial expansion had taken the empire into the steppes of Ukraine and Central Asia, widely regarded as original homelands of the horse.${ }^{17}$ Not only were these areas characterized by native equestrian cultures, they also secured a ready flow of animals capable of reproducing under minimal supervision. ${ }^{18}$ From the reign of Catherine II, horses were plentiful, even in exceptional circumstances. The empress herself requisitioned 13,640 on her return from the Volga in 1767 and more than 41,800 twenty years later, when every Russian province contributed to her great expedition to the South. ${ }^{19}$ Even in wartime, when the urgent need for remounts allowed less time for procurement and thousands of animals had to be

\footnotetext{
${ }^{17}$ Pita Kelekna, The Horse in Human History, 2nd edn, Cambridge, 2012, ch. 2, esp. pp. 29, 32, Fig. 2.1, pp. 30-31; V.B. Kovalevskaia, Kon' $i$ vsadnik: Istoriia odomashnivaniia loshadei v evraziiskikh stepiakh, na Kavkaze i Blizhnem Vostoke, Moscow, 2019. ${ }^{18}$ Shane O'Rourke, The Cossacks, Manchester, 2007; Sean McDaniel, “'Our Greatest Riches": Horses at the Intersection of Settler and Kazakh Society in the Late Imperial Period', Journal of Migration History, 3, 2017, pp. 210-28. On resilient steppe-herds (tabuny), see J.G. Kohl, Russia, London, 1842, pp. 487-95.

${ }^{19}$ N.V. Bessarabova, Puteshestviia Ekateriny II po Rossii, Moscow, 2005, pp. 43, 48.
} 
concentrated on a distant front, the Russian horse industry proved capable of a rapid response. When the thaw came in spring 1813 , some 120,000 carcasses were revealed in Smolensk province alone. ${ }^{20}$ Nevertheless, whereas Napoleon failed to replace French losses totalling 175,000 head during the Russian campaign, Alexander I replenished his cavalry by conscripting animals instead of men. Almost 62,000 cavalry horses were mobilized over the winter of 1812-13, mostly from private studs; draughthorses must have been more numerous still. ${ }^{21}$ As the success of such emergency measures implied, there was no shortage in less troubled times. By the mid-1850s, Russia's postal system could rely on more than 50,000 horses. $^{22}$

Such bountiful provision consistently confounded expectations of decline. In 1882, the first comprehensive equine census counted 19,637,625 horses in European Russia, excluding Finland and the Caucasus. Its compilers estimated that a further 1.5 million should be added to account for the Don, Astrakhan and Kirghizia, and parts of the provinces of Perm', Archangel and Vologda. Even without them, a total of 14,883,696 horses of working age gave an overall ratio of approximately one horse for every able-bodied adult male. 'Contrary to prevailing opinion', the census-takers insisted, the number of horses had risen by a minimum of 23 per cent in eighteen years, faster than the population. ${ }^{23}$ By 1912 , Russia could boast almost 33 million horses - 20.4 for every 100 inhabitants, a ratio outclassed only by two global outliers: Argentina (82.2:100 in 1895) and Uruguay (53.3:100 in 1908). The

\footnotetext{
${ }^{20}$ Janet M. Hartley, 'Russia in 1812, Part 1: the French Presence in the Gubernii of Smolensk and Mogilev', Jahrbücher für Geschichte Osteuropas, 38, 1990, 2, p. 197.

${ }^{21}$ Dominic Lieven, Russia against Napoleon: The Battle for Europe, 1807 to 1814, London, 2009, pp. 7-8, 27-8, 306-7, 350-51; idem, 'Mobilizing Russian Horsepower in 1812', History, 96, no. 322, 2011, pp. 152-66.

${ }^{22}$ Randolph, 'Communication and Obligations', p. 155.

${ }^{23} \mathrm{P}$. Semenov, 'Obshchii obzor konevodstva po dannym perepisi 1882 goda', Konskaia perepis' 1882 goda, St Petersburg, 1884, pp. ix, xxxix. On the conduct of this and other equine censuses, see D.A. Tarasiuk, 'Voenno-konskie perepisi kontsa XIX - nachala XX vv.', Istochnikovedenie otechestvennoi istorii, 1989 g., Moscow, 1989, pp. 98-132.
} 
USA stood roughly parallel to Russia (21.6:100 in 1910). Of the European states, only Denmark came close (19.8:100 in 1908), and Denmark was not a great power. As they were uncomfortably aware, Russia's main international rivals - Austria-Hungary (8.4:100 in 191011), Germany (6.9:100 in 1911-12), and Great Britain (4.5:100 in 1911) - all lagged well behind. $^{24}$

Russia's horse industry was nevertheless beset, like the economy as a whole, more by problems of distribution than by problems of production. A marked contrast emerged between the Ukrainian steppes, where horses were naturally plentiful, and the long-settled black-earth provinces south of Moscow, where specialist breeders were concentrated. Whereas the 1882 equine census showed an increase in New Russia of approximately 200 per cent since 1864, the provinces of Riazan', Tula, Tambov, and Voronezh, at the heart of Russian horse-breeding, had suffered a combined loss of approximately 3 per cent. ${ }^{25}$ In the most densely populated part of the empire, this disparity created a shortage of even peasant horses (small, scraggy beasts constituting almost 85 per cent of the total) and provided the incentive for Ukrainian dealers to drive their herds north to an expanding range of horse-fairs. By 1880, these numbered 1079 at 471 different trading points, eclipsing the four annual fairs at Lebedian in Tambov province which had generated an annual turnover of 5-6 million roubles between the 1830 s and the $1850 \mathrm{~s}^{26}$ In those decades the balance of resources favoured the animals even when natural disasters attacked man and beast simultaneously. At the Gagarin stud at Petrovskoe, better known to historians as the subject of Steven Hoch's

\footnotetext{
${ }^{24}$ Voennaia-konskaia perepis' 1912 goda, Statistika Rossiiskoi Imperii, 83, Petrograd, 1914, p. iii. For an American view of Europe, see George M. Rommel, The Army Remount Problem, Washington DC, 1911, pp. 103-6. On the ingenuity of British remount officers, see John Singleton, 'Britain's Military Use of Horses 1914-1918', Past and Present, 139, 1993, pp. 178-203. ${ }^{25}$ Konskaia perepis' 1882 goda, pp. xxxvii-xxxviii.

${ }^{26}$ I. Aksakov, Izsledovanie o torgovle Ukrainskikh iarmarkakh, St Petersburg, 1858, pp. 28186; N.V. Krivoshein, Lebedianskoe skakovoe obshchestvo: istoriia, uchastniki, dokumenty, Moscow, 2011, pp. 14-25.
} 
classic study of serfdom, 'the number of horses held up remarkably well' during the famine of 1833-4, when 'two-thirds of the households were found to be completely without grain'. ${ }^{27}$ In any normal year, there was not a shortage of horses in Russia but a glut.

Prices were consequently depressed. This point was grasped in 1952 by the Soviet animal husbandry specialist, V.O. Vitt, an equine enthusiast who had abandoned his career as a lawyer shortly after publishing a prizewinning thesis on Catherine II's Nakaz in 1909. In response to Stalin's appeal for research to outflank Western science, Vitt duly lauded the merits of socialist planning. But his history stressed the power of market forces. While recurrent wars kept supply and demand in rough equilibrium in the eighteenth century and horse prices rose sharply during the Napoleonic invasion, the ensuing peace drove them into decline. ${ }^{28}$ In 1831 , a nine-year service period was imposed for cavalry horses, generating an annual remount of $1 / 9$ of the total force, barely a fifth of the level of 1814 . By the time this system was renewed in 1868 , the price of a cavalry officer's riding horse had almost halved. Throughout the intervening period, regimental commanders complained that their budgets were set too low to meet the demands of breeders who put a premium on prestige animals of the requisite age and size ${ }^{29}$ Breeders, by contrast, were alarmed by the proliferation of steppe horses - hardy, self-reliant steeds, smaller than thoroughbreds, which re-emphasized their indispensability to the light cavalry against the Ottomans in 1828-29. 'Steppe horses may be highly useful for war', warned a prominent stud-owner in 1835 , 'but they will be the ruin rather than the foundation of horse-breeding in Russia' ${ }^{30}$ His forecast was prophetic. Already

\footnotetext{
${ }^{27}$ Steven L. Hoch, Serfdom and Social Control: Petrovskoe, an Estate in Tambov, Chicago, 1986, pp. 54, 46, table 10.

${ }^{28}$ V.O. Vitt, Iz istorii russkogo konnozavodstva: Sozdanie novykh porod loshadei na rubezhe XVIII-XIX stoletii, Moscow, 1952, pp. 3, 332-36.

${ }^{29}$ V.V. Ermolov and M.M. Ryndin, Upravlenie general-inspektora kavalerii o remontirovanii kavalerii: Istoricheskii ocherk, St Petersburg, 1906, p. 180; Polnoe sobranie zakonov Rossiiskoi Imperii (PSZ), 2nd series, xliii, no. 45530 (24 Feb. 1868).

${ }^{30}$ N.A. Lunin to Count M.S. Vorontsov, 23 May 1835, in Krivoshein, Lebedianskoe skakovoe obshchestvo, p. 260.
} 
in 1837, Russian studs held 200,000 head more than in 1814, an unsustainable level of unsold stock mitigated only by exports. ${ }^{31}$ Even thoroughbreds traded at a discount. At the Rostopchin stud in Voronezh province in 1843, Haxthausen found four-year-old mares for sale at prices that seemed 'ridiculously low, for horses of the highest breeding, which would fetch twice, three, and even four times as much anywhere else in Europe'. ${ }^{32}$

In an attempt to reconcile the interests of state and private breeders, successive Russian governments repeatedly tinkered with the bureaucracy. ${ }^{33}$ Before the Napoleonic invasion, the state stables were administered by the imperial Court, widely believed to have privileged horses' external appearance over their capability for work. After Napoleon's defeat, control passed to two brothers-in-law, Prince Ilarion Vasil'chikov and V.V. Levashev, light-cavalry commanders who joined the cohort of victorious generals in Nicholas I's government. ${ }^{34}$ When Vasil'chikov was appointed president of the State Council in 1838, its vacation was postponed to allow him to spend September on horseback in the country. 'He is a passionate enthusiast', noted Baron Korff, 'and this alone restores his strength every year'. ${ }^{35}$ However, there was nothing sentimental about Vasil'chikov's response to falling military demand. By closing and merging surplus Court and military stables and capping the

\footnotetext{
${ }^{31}$ Vitt, Iz istorii russkogo konnozavodstva, p. 332.

${ }^{32}$ Baron von Haxthausen, The Russian Empire: Its Peoples, Institutions, and Resources, trans. Robert Farie, 2 vols, London, 1856, 1, p. 380.

${ }^{33}$ Ivan Merder, Istoricheskii ocherk russkago konevodstva i konnozavodstva, St Petersburg, 1868, and N. Zeziulinskii, Istoricheskoe izsledovanie o konnozavodskom dele v Rossii, 3 vols, St Petersburg, 1889-93, cleave to the legislative record indexed by A.A. Il'menskii, Ukazy $i$ pravitel'stvennyia rasporiazheniia otnosiashchiesia do gosudarstvennago konnozavodstva $i$ konevodstva v Rossii za 260 let, s 1649 po 1909 god, St Petersburg, 1910. See also Erik Amburger, Geschichte der Behördenorganisation Russlands von Peter der Grossen bis 1917, Leiden, 1966, pp. 255-57, and a profusion of recent online articles by D.A. Mel'nikova. This subject merits further investigation.

${ }^{34}$ Grigorii Bibikov, 'Heroes of the Napoleonic Wars in the Ruling Elite of the Russian Empire', in Janet M. Hartley, Paul Keenan and Dominic Lieven (eds), Russia and the Napoleonic Wars, Basingstoke, 2015, esp. p. 213, tables 15.1 and 15.2.

${ }^{35}$ M.A. Korf, Dnevniki 1838 i 1839 gg., ed. I.V. Ruzhitskaia, Moscow, 2010, p. 106 (27 Apr. 1838), original emphasis.
} 
remainder, he claimed to have converted a deficit of 137,512 roubles on a budget of 779,708 in 1823 into a surplus of 105,023 roubles ten years later. One aim was to supply the guards with an annual remount of 311 stallions, bred largely from English bloodstock. But Vasil'chikov also introduced, in revised form, a project first contemplated under Alexander I. In 1833, the Committee of Russian Horse-breeding established six provincial stables, where peasants could have their mares covered for between 25 and 100 paper roubles. ${ }^{36}$

Because these rates were in practice accessible only to noble stud-farmers, General P.D. Kiselev determined to secure a better deal for the state peasants at the heart of his reforms as Minister of State Domains from $1837 .{ }^{37}$ In 1843, he went further, absorbing the government's horse-breeding establishment into his own ministry. The creation of the State Horse-breeding Board seemed a triumph for Levashev, a rising political star who had Vasil'chikov's support for a reform which promoted him to ministerial status. However, as his rival Admiral A.S. Menshikov quipped, Levashev was too old to be a 'state stallion' and his ambitions were thwarted when it emerged that a place on the Committee of Ministers was incompatible with his existing role as head of the State Council's economic department. ${ }^{38}$ While Levashev nominally led the Board until his death in 1848, strategic direction passed to the more sophisticated Kiselev in a move that signalled a shift in priorities away from the cavalry towards wider economic needs.

Over four years from 1844, the studs in the military colonies, created under Alexander I, were abolished while other military studs were converted to civilian purposes, notably the

\footnotetext{
${ }^{36}$ Zeziulinskii, Istoricheskoe izsledovanie, 3, pp. 92-8; PSZ, 1st series, xxxviii, no. 29466 (15 May 1823), esp. p. 203; 2nd series, viii, no. 5933 (24 Jan. 1833).

${ }^{37}$ Tatiana Andreeva, 'Na puti k reforme: Vopros o kazennykh krest'ianakh v sekretnykh komitetakh Nikolaevskogo tsarstvovaniia', Quaestio Rossica, 7, 2019, 1, 39-54, suggests the need for a close modern study of measures designed to improve the condition of the peasantry while simultaneously increasing their profitability to the state.

${ }^{38}$ PSZ, 2nd series, xviii, no. 16729 (10 Apr. 1843); M.A. Korf, Dnevnik: God 1843-y, ed. I.V. Ruzhitskaia, Moscow, 2004, pp. 145-46 (27 Mar.), 270 (21 Aug.).
} 
development of draughthorses. The ministry also expanded the range of provincial stables where peasants were offered access to state-owned sires. ${ }^{39}$ To improve supply, in 1845 the state purchased Russia's best-known stud at Khrenovo, established in Voronezh province by Count A.G. Orlov-Chesmenskii. There could have been no more symbolic demonstration of the government's determination to link improvements in horse-breeding to the development of peasant agriculture.

When Kiselev went to Paris as ambassador in 1856, the State Horse-breeding Board regained its independence under two Baltic German cavalrymen: Georg, Freiherr von Meyendorff (1856-9), and Baron Moritz Grünewaldt [Rodion Egorovich Grinval'd] (185974). On Grünewaldt's retirement, P.A. Valuev reluctantly resumed responsibility for the stables as Minister of State Domains. Horses bored Valuev, who went racing only once - in February 1874 at the 'insistent desire' of Prince V.D. Golitsyn, a former cavalry commander in charge of the Court stables who had joined Meyendorff at the forefront of harness-racing in St Petersburg at its inception in the 1840s. Nevertheless, Valuev was prepared to suffer even 'an hour of discourse about stallions' to prevent the breeding industry from falling into the hands of the cavalry's inspector-general, Grand Duke Nikolai Nikolaevich: 'any grand ducal administration is in principle harmful' ${ }^{40}$ Only under Alexander III did the Horsebreeding Board again split from the ministry. Under Count I.I. Vorontsov-Dashkov, who dominated racing in the era of the tote, it retained responsibility for the state stables with a reduced budget of 175,100 roubles, though the government continued to contribute under

\footnotetext{
${ }^{39}$ Zeziulinskii, Istoricheskoe izsledovanie, 3, pp. 99-105. On the military colonies, start from work listed by A. Bitis and Janet Hartley, 'The Russian Military Colonies in 1826', Slavonic and East European Review, 78, 2000, 2, p. 321, n. 1.

${ }^{40}$ Dnevnik P.A. Valueva, ed. P.A. Zaionchkovskii, 2 vols, Moscow, 1961, 2, p. 308 (8 Apr. 1874); p. 300 (24 Feb. 1874); p. 329 (15 Jan. 1876); PSZ, 2nd series, xlix, no. 53375 (17 Apr. 1874).
} 
other heads, including 100,000 roubles in prize-money for the officers' races established by Grand Duke Nikolai in $1867 .{ }^{41}$

Against this backdrop of bureaucratic in-fighting, belief in the value of racing remained constant from the mid-1820s. By trialling the best horses, racing challenged studowners to beat the flooded market by emphasizing quality rather than quantity and developing breeds capable of combining speed with endurance. Owners looked back to a golden age dominated by Orlov-Chesmenskii and Count F.S. Mosolov, who rapidly acquired semi-mythical status as the sport's founding fathers. ${ }^{42}$ Orlov's shade loomed particularly large thanks to the breeding experiments begun in the 1760s on his estate at Ostrov near Moscow and developed at Khrenovo following his return from the Mediterranean in 1775. By the mid-1780s, he had organized races for thoroughbreds and trotters that flourished in Moscow until his death in $1808 .^{43}$ Only from 1825 was racing restored, this time on an institutionalized basis with a wider range of competitors. ${ }^{44}$ Apart from a brief period of centralized control between 1845 and 1847, races were managed by elite societies regulated by the state. But whereas Orlov had conceived thoroughbred- and harness-races in parallel, the two formats came increasingly into competition, representing by the mid-nineteenth century not only rival equine values but contrasting equestrian cultures.

${ }^{41}$ PSZ, 3rd series, i, no. 238 (1 June 1881); ii, no. 827 (27 Apr. 1882). Compare ibid., 2nd series, xlii, no. 44223 (9 Feb. 1867). Vorontsov-Dashkov was simultaneously minister for the Court, but his equestrian responsibilities were separate.

${ }^{42}$ Moskovskiia skachki, ili slabye ocherki iz zhizni dvukh znamenitykh konno-zavodchikov v Rossii grafa Alekseia Grigor'evicha Orlova-Chesmenskago i Fedora Semenovicha Mosolova: V stikakh, Moscow, 1848.

${ }^{43}$ Oleg Ivanov, Graf Aleksei Grigor'evich Orlov-Chesmenskii v Moskve, Moscow, 2002, pp. 160-69, 318-28.

${ }^{44}$ A variety of informal peasant races continued across the empire, just as they had always done. One British traveller in the early 1820s, who 'never saw a people with more spirit of gambling' than the Yakuts, reported a wager to ride 170 miles in twenty-four hours, 'not by any violent exertion, but by regular trotting, which would astonish the sporters of Old England'. See John Dundas Cochrane, A Pedestrian Journey through Russia and Siberian Tartary, to the Frontiers of China, the Frozen Sea, and Kamchatka, 2 vols, Edinburgh, 1829, 1, p. 186. 


\section{English thoroughbred-racing in Russia}

The defining event in establishing the pre-eminence of the English thoroughbred in Russia took place on 4 August 1825. To settle a wager between the diplomat Count A.F. Matusevich (1795-1842) and the Don Cossack general, Count V.V. Orlov-Denisov (1775-1843), egged on by Vasil'chikov and Levashev, two English horses raced two Don Cossack horses along the road from St Petersburg to Gatchina and back, a distance of 74 versts (49 miles). ${ }^{45}$ 'Much distressed' after bolting up Pulkovo Hill, Matusevich's horse, Sharper, bred by the earl of Egremont and ridden by Thomas Archer, completed the course in two hours forty-eight minutes and forty seconds, eight minutes faster than the sole surviving Cossack horse, which carried a lighter weight. Crowds lined the streets to watch the contest, which rapidly achieved international celebrity. ${ }^{46}$

By then, the foundations had already been laid for Russia's first thoroughbred-racing society at Lebedian, whose location at the junction of the Asian and Ukrainian trades raised the town's significance out of all proportion to its size. The society was the brainchild of a relatively impecunious young landowner, Colonel P.A. Miasnov, whose anglophile friends applied to form a society in February 1825. Undeterred by the provincial authorities' insistence on detailed regulations, the collaborators staged unauthorized races during the September 1825 horse-fair before drafting a statute on the English model, approved in October 1826. Supplementary regulations stipulated distances of between two and thirty

\footnotetext{
${ }^{45}$ Matusevic later befriended the English sporting writer, 'Nimrod': see Nimrod, 'Foreign Sporting', New Monthly Magazine, 62, no. 245, May 1841, p. 51-3; Norman Gash, 'Apperley, Charles James [pseud. Nimrod] (1778-1843)', Oxford Dictionary of National Biography.

${ }^{46}$ The Times, 10 and 17 Sept. 1825, informed William Youatt, The Horse, 4th edn, London, 1874, p. 49. Staatsrath von Hazzi, Ueber die Pferderennen, als wesentliches BeförderungsMittel der bessern, vielmehr ehlen Pferdezucht in Deutschland und besonders in Bayern, Munich, 1826, p. 29, was translated into Russian in 1827.
} 
versts (1.3 and 19.8 miles) for three- and four-year-olds ridden by jockeys wearing the colours of their respective stables and weighing no less than 3 puds and 10 funts (approximately 8 st. 5 lbs; English jockeys weighed between 7 and 8 stones). Nervous of appearing dependent on foreigners after the Decembrist revolt, Miasnov ironically ceded prominence to his wealthier friend, N.A. Lunin, whose republican cousin, Mikhail, had advocated the liquidation of the imperial family. Since this proved no obstacle, Lunin was confirmed as president at the society's inaugural meeting in May 1827, when Vasil'chikov, Levashev and Prince V.D. Golitsyn were among those elected to honorary membership. ${ }^{47}$

Such a powerful constellation soon tired both of provincial isolation and of contests from which English thoroughbreds were excluded. By 1831, Miasnov and his friends were agitating to race in Moscow. Lebedian, they argued, was too isolated to influence breeding on a national scale: leading owners could not attend races; specialist grooms were lacking; crowds were small. Moscow promised a richer future. All horses born in Russia and the Kingdom of Poland were to be recognized as Russian and permitted to compete with those from 'Arabia, Persia, and other Asian lands'. But horses 'brought from England, or born on board ship' were eligible only for designated races, irrespective of their breed. The superiority of the English model was clear. Members who subscribed for five years in advance at an annual fee of 3000 roubles (compared with 60 roubles at Lebedian) acquired the exclusive right to import English horses, to receive information about English races, and to import from England 'experienced grooms, jockeys and stud superintendents, and also racing calendars, portraits of horses, stud-books and other literature related to breeding'.

${ }^{47}$ Krivoshein, Lebedianskoe skakovoe obshchestvo, pp. 19-20, 51-68. On the Lunins, see M.S. Lunin, Pis'ma iz Sibiri, eds I.A. Zhevakova and N.Ia. Eidel'man, Moscow, 1987, pp. 266-68. 
Small wonder that the society's promoters believed that Moscow could soon 'compare with Doncaster, Epsom and Newmarket' ${ }^{48}$

In fact, Russian hippodromes resembled elite Newmarket, where crowds rarely exceeded 500 in the 1830s, more than Epsom, where the fair drew over 100,000 on Derby Day. It seems unlikely that any Russian attendance matched the 15,000 attracted by Count István Széchenyi to Hungary’s races. ${ }^{49}$ Indeed, except for Orlov’s hippodrome near the Don monastery, memorably described by S.P. Zhikharev, much remains obscure about early Russian racecourses. ${ }^{50}$ By 1832 , one had opened on the south-western edge of Moscow, beyond Ostozhenka Street, the site of several stables. However, racing soon moved to Khodynka in the north-west, where harness-racing had begun in 1834 close to the present-day hippodrome. The precise location of the Lebedian racecourse on the left bank of the Don is also uncertain though, like other Russian and English courses before 1870, it was open rather than enclosed. While noble guests were invited to the pavilion, others probably watched from the hillside across the river. ${ }^{51}$

\footnotetext{
${ }^{48}$ PSZ, vi, no. 4308 (31 Jan. 1831), 'Zapiska Maiora Maslova'; ibid., 'Polozhenie o uchrezhdenii v Moskve Obshchestva Skakovoi Okhoty’, para. 8; Ustav otdeleniia Obshchestva Moskovskoi Konnoi Skakovoi Okhoty, Moscow, 1832, pp. 18-19, paras. 65-7. ${ }^{49}$ Vamplew, The Turf, p. 26; Graf Stephan Szechenyi, Ueber Pferde, Pferdezucht und Pferderennen, trans. Joseph Vojdisek, Leipzig, 1830; R.J.W. Evans, 'Széchenyi and Austria', in T.C.W. Blanning and David Cannadine (eds), History and Biography: Essays in Honour of Derek Beales, Cambridge, 1996, p. 115; András Vári, 'Angol játék a Magyar gyepen: A Magyar Gazdasági Egyesület előtörténete’, Korall, 19-20, 2005. In Hungary and elsewhere, enthusiasm for English horse-racing was often combined with Whiggish political views which found no sustained reflection among Russian anglophiles. Most were, after all, serf owners reliant on unfree labour for their grooms, jockeys and stable-lads.

${ }^{50}$ S.P. Zhikharev, Zapiski sovremennika, 2 vols, Leningrad, 1989, 1, pp. $83-5$ (4 May 1805). Zhikharev joined the State Horse-breeding Board in Dec. 1843, resigning bankrupt in 1847. ${ }^{51}$ V. Androssov, Statisticheskaia zapiska o Moskve, Moscow, 1832, pp. 15-16; M. Zakharov, Ukazatel' Moskvy, 2 vols, Moscow, 1851, 1, p. 203; Krivoshein, Lebedianskoe skakovoe obshchestvo, pp. 69-71.
} 
English-style races in New Russia began even before 1825. At the Odessa raceground in May 1822, Dr Robert Lyall and his companions 'could almost have believed ourselves transported to England':

Numerous tents were pitched, the course was roped in, and an immense concourse of people, of all ranks, was assembled on foot, or drove about in different kinds of German, French, Polish, Russian, and even English, carriages. English gentlemen dressed in all the gaudy livery of jockeys, rode their own horses, nine of whom started, and four were distanced in the first heat.

Nevertheless, all was not quite what it seemed. In the third heat, a Cossack, 'mounted upon an old half-starved black poney', passed the winning-post alongside the leading thoroughbred, 'to the great amusement of the spectators'.52 More regular arrangements awaited the annual races established under Count M.S. Vorontsov, appointed governorgeneral of New Russia in the following year. Educated in England as the son of Catherine II's ambassador, Vorontsov was an honorary member of the Lebedian society who saw racing as a way of boosting his territories' prestige. ${ }^{53}$ By 1829 , he had extended the races to the Crimea. Although the Tauride's governor reported that the 'first experiment' at Simferopol' had been 'fairly successful', the note of caution proved prudent since one winning owner sold off not only all his horses, but also the cup donated by Vorontsov. Still, it was worth investing in another since the future looked more promising. 'Up to this point, we have been apprentices', A.I. Kaznacheev admitted in 1832, ‘but now we are becoming more experienced and more knowledgeable'. ${ }^{54}$ A degree of professionalism was evident by 1839 ,

\footnotetext{
${ }^{52}$ Robert Lyall, Travels in Russia, the Krimea, the Caucasus, and Georgia, 2 vols, London, 1825,1, p. 184. Napoleon's officers had unwisely shared this condescension towards small, unkempt steppe horses which proved faster and stronger than they expected.

${ }^{53}$ Anthony L.H. Rhinelander, Prince Michael Vorontsov: Viceroy to the Tsar, Montreal, 1990, p. 118.

${ }^{54}$ A.I. Kaznacheev, Partikuliarnye pis'ma k grafu M.S. Vorontsovu, 1827-1838 gg., ed. A.K. Afanas'ev, Moscow, 2015, p. 46 (18 Nov. 1829); p. 116 (16 Feb. 1832).
} 
when Vorontsov, fresh from a trip to Epsom with the tsarevich, presented the prizes on 14 October. The winning owners included his cousin and sporting rival, Major-General L.A. Naryshkin, whose jockey, dressed in black cap, light-blue jacket and yellow jodhpurs, weighed in at 3 puds and 38 funts (9 st. 11 lb.). ${ }^{55}$ Even so, Miasnov sneered, prize money capped at 1500 roubles condemned New Russia's races to second-rate status 'because the horses there are the most insignificant and landowners convinced of their superiority will forever remain under the same delusion', 56

Prospects seemed stronger in Tula, where Miasnov became vice-president of the racing society established in 1838 . Founded seventy years earlier by Count P.B. Sheremetev, the province's best-known stud at Serebrianye prudy housed around 500 horses at its peak. I.P. Petrovskii's operation outgrew even that, and the province was home to a range of rival owners, including Miasnov himself. ${ }^{57}$ The Tula society required members to visit such establishments annually to seek information for supplements to the first Russian stud-book, published in 1836 on the English model of 1791. This was soon complemented by the first directory of Russian studs, likewise compiled under the supervision of the Committee of Russian Horse-breeding, for whom Lunin had directed the military studs since $1834 .{ }^{58}$

Russian horse-racing deviated from English practice in only two major respects. By racing on Sundays, its organizers followed a continental example unthinkable in England where the 1780 Lord's Day Observance Act was still partially in force two centuries later and Sunday racing began only in $1992 .{ }^{59}$ Since almost every nineteenth-century Russian traveller

\footnotetext{
${ }^{55}$ Pribavleniia $k$ Tavricheskim gubernskim vedomostiam, 21 Oct. 1839.

${ }^{56} \mathrm{P}$. Miasnov, O vospitanii skakovykh loshadei v Rossii i prigotovlenii onykh $k$ skachke, Moscow, 1833, p. 54.

${ }^{57}$ Statisticheskoe obozrenie konnozavodstva Rossii, St Petersburg, 1847, pp. 138-43.

${ }^{58}$ PSZ, xiii, no. 11573 (30 Sept. 1838), 'Proekt ustava', para. 16; Zavodskaia kniga krovnykh i skakavshikh loshadei v Rossii, St Petersburg, 1836; Podrobnye svedeniia o Rossiiskom konnozavodtsve, St Petersburg, 1839.

${ }^{59}$ The Journals of Woodrow Wyatt: Volume 1, ed. Sarah Curtis, London, 1999, pp. 8, 377.
} 
commented on the austerity of the English Sabbath, it was social rather than religious constraints that determined the second contrast between racecourses in Russia and England: a lack of carnival spirit which in turn permitted the presence of society ladies, strangers to English courses before they were enclosed. ${ }^{60}$ Accompanying the tsarevich to Epsom in 1839, Vasilii Zhukovskii was struck by 'confusion in a tight place' and 'fights at the barrier' ${ }^{61}$ At Tsarskoe Selo, the atmosphere was more decorous. Except among the English jockeys, there was no betting and it seemed to Richard Cobden in 1847 that something was missing: 'The Emperor \& his family \& a good muster of fashionables were present on the course, but the amusements wanted life $\&$ animation, which nothing but a mass of people capable of feeling $\&$ expressing an interest in the sports of the day can present. ${ }^{, 62}$

Cobden travelled to Tsarskoe Selo with British merchants in St Petersburg, who had staged their own races 'in true English style' a decade earlier and had 'the satisfaction of seeing the Russians beginning to imitate them'. ${ }^{63}$ The British could look back over eighty years of hunting on the Peterhof road, where they rubbed shoulders with Russian grandees at their summer estates. ${ }^{64}$ English horses also served as instruments of diplomacy, especially during the embassy of the marquis of Clanricarde (1838-41), a keen steeplechaser who had scandalized the Parisian beau monde in 1835 'by riding a race in the Bois de Boulogne in a

${ }^{60}$ Compare Mike Huggins, Flat Racing and British Society, 1790-1914: A Social and Economic History, London, 2000, ch. 5: 'The Greatest Carnival of the Year'. ${ }^{61}$ V.A. Zhukovskii, Polnoe sobranie sochinenii i pisem, ed. A.S. Ianushevich et al., 14 vols (Moscow, 2004-), 13, p. 171, diary (3/15 May 1839).

${ }^{62}$ The European Diaries of Richard Cobden, 1846-1849, ed. Miles Taylor, London, 1994, p. 195 (12 Sept. 1847).

${ }^{63}$ Robert Bremner, Excursions in the Interior of Russia, 2nd edn, 2 vols, London, 1840, 1, p. 216 (1836).

${ }^{64}$ Memuary S.D. Sheremeteva, eds. L.I. Shokhin and K.A Vakh, 3 vols, St Petersburg, 20015, 2, pp. 202-3; 'A word or two about "Garella": The British hunt kennel in Russia', Sporting Magazine, Apr. 1830, pp. 386-89. Other aspects of estate culture are highlighted by Stephen Lovell, Summerfolk, 1710-2000: A History of the Dacha, Ithaca, 2003, pp. 28-57. 
yellow and white striped jacket, and cap to match' ${ }^{65}$ It was thanks to Clanricarde that the Sporting Review published extracts from Zhikharev's report on the Lebedian races of $1841 .{ }^{66}$ Earlier that year, a tense moment in Anglo-Russian relations, after the Khivan envoy in St Petersburg had been 'decoyed' to the opera by his tsarist hosts, Clanricarde preferred to show off his English horses: 'He seemed a good deal struck by their size and appearance, and was infinitely more at his ease in the Riding-School than in any other place in which I have seen him. ${ }^{67}$ In the mid-1840s, the imperial stud near Oranienbaum housed both the appropriatelynamed Ambassador, purchased from Clanricarde, and Argyle, winner of a race organized at Strel'na by his predecessor, the earl of Durham. Intended partly as a signal of quality, the tradition of naming an elite horse after the seller was already well established in England in the late seventeenth century. By the same token, the British envoy to Sweden was flattered to discover on a visit to Russia in 1825 that the future Nicholas I had named one of his English horses Bloomfield. ${ }^{68}$

A feature of the anglomania characteristic of the age of Catherine II, British agents had been central to Russian thoroughbred-racing since the arrival of John Banks in the 1780s. By then, English imports were estimated annually at between 200 and 300 head. ${ }^{69}$ The circus impresario Charles Hughes, who organized a race on Vasilii Island in 1792 and served as horse-breaker to the empress and her entourage, had been recommended as an agent to

${ }^{65}$ Letters of Harriet Countess Granville 1810-1845, ed. Hon F. Leveson-Gower, 2 vols, London, 1894, 2, p. 184 (12 Feb. 1835), to the duke of Devonshire; John Maunsell Richardson and Finch Mason, Gentlemen Riders Past and Present, London, 1909, pp. 1-3. ${ }^{66}$ Sporting Review, Mar. 1842, pp. 211-15.

${ }^{67}$ The National Archives, London (hereafter TNA), FO 65/271, Clanricarde to Palmerston, 13 Jan. 1841.

${ }^{68}$ Statisticheskoe obozrenie, p. 274; Edwards, Horse and Man (above, n. 5), p. 25; Memoir of Benjamin Lord Bloomfield, ed. Georgiana Lady Bloomfield, 2 vols, London, 1884, 2, p. 35. ${ }^{69}$ Anthony Cross, 'By the Banks of the Neva': Chapters from the Lives and Careers of the British in Eighteenth-Century Russia, Cambridge, 1997, pp. 20, 43. 
Aleksei Orlov by Sir John Dick, the British consul at Leghorn. ${ }^{70}$ From 1820, Richard Walkden was contracted to supply the state with eleven stallions a year. When Walkden returned home in 1827, another Lincolnshire man, John Ashton, replaced him. The York breeder, Thomas Kirby, was also active in Russia for almost forty years, having 'first set foot at Cronstadt in 1791, when he was little more than twenty-one, in charge of a string of horses, which a speculative Market Weighton brewer sent out at a venture' ${ }^{71}$ But it was a fellow Yorkshireman, John Jackson, introduced to Moscow by Banks at the turn of the century, who dominated the Russian thoroughbred trade for the next fifty years. Russia's leading equestrian journalist, Vasilii Koptev, remembered childhood visits to Jackson's stables on Ostozhenka, where the proprietor's broken Russian inadvertently transposed English (angliiskie) horses into angelic (angel'skie) ones. ${ }^{72}$ However idiosyncratic his sales technique, his success was incontrovertible. 'Mr Jackson has regularly drawn off to Russia some of the finest animals we produce', complained an habituée of the Howden horse fair to the British Foreign Secretary at the beginning of the Crimean War, 'to which, doubtless, may be ascribed the superior mounting of the Russian soldiers now opposed to ours' ${ }^{73}$ Using information supplied by Jackson himself, the Russian stud-book dedicated separate sections to his activities, showing that by 1836 he had delivered a total of 125 mares and 155 stallions to Russia's leading breeders. Orlov, Mosolov and Prince N.S. Gagarin, born in London in

\footnotetext{
${ }^{70}$ Cross, 'By the Banks of the Neva', p. 20; John M. Turner, 'Hughes, Charles (1746/7-1797)', Oxford Dictionary of National Biography. On the friendship between Dick and Orlov, see M.S. Anderson, 'Great Britain and the Russian Fleet, 1769-70', Slavonic and East European Review, 31, no. 76, 1952, pp. 158-59. Eighteenth-century equestrian links between Britain and Russia merit further investigation. So does trick-riding in both cavalry and circus, a skill exemplified by Hughes that owed much to American influences by Soviet times.

71 The Druid [Henry Hall Dixon], The Post and the Paddock, 2nd edn, London, 1867, p. 74. Kirby was Dixon's main informant on Russia, 'his theme of themes': Sporting Review, Mar. 1858, p. 154.

${ }^{72}$ Materialy dlia istorii russkogo konnozavodstva: Stat'i Vasiliia Ivanovicha Kopteva 18471887, Moscow, 1887 (hereafter, Materialy), p. 157.

${ }^{73}$ TNA, FO 65/455, Cath. A. Taylor to Clarendon, 7 Apr. 1854. For complaints about Jackson in his heyday, see Sporting Review, Feb. 1839, p. 143.
} 
1784, ranked among his clients; so did the Pashkovs and the Voeikovs. Another regular customer, I.P. Petrovskii, claimed in his own study of English bloodstock imports that Jackson's figures understated his contribution by as much as 50 per cent. ${ }^{74}$

'The English Stud Book is his Koran', wrote Britain's leading correspondent of Petrovskii, the first Russian owner to race at Newmarket, 'and in his library may also be found every Racing Calendar and Sporting Magazine that has ever seen the light'. Though Petrovskii's anglomania was easily mocked - all his dogs and pigs were English, 'but we are not so sure of his fighting geese' - his enthusiasm was widely shared. ${ }^{75}$ While Lunin visited Britain in 1833 in search of bloodstock for the Committee for Russian Horse-breeding (Birmingham, the 1830 St Leger winner, was among his purchases), other pillars of the Lebedian society admired from afar. D.P. Voeikov was still importing English thoroughbreds on the eve of the Crimean War, a decade after commissioning a portrait showing him with his daughter, her English governess and a statue of a white stallion. ${ }^{76}$ When V.G. Belinskii, a more radical Westernizer, caricatured in 1843 the wealthy angloman whose 'anglicized horses, jockeys and grooms' looked 'as if they had been brought straight from London', this was the fraternity he had in mind. ${ }^{77}$

Although Zhikharev pronounced 'our home-grown Robinsons and Scotts' more daring than the 'cautious English jockeys' at Lebedian in 1841, it was a Newmarket man,

\footnotetext{
${ }^{74}$ Zavodskaia kniga, pp. xxxviii-xlii, liii-lvii; Materialy, pp. 156-57, quoting N.S. [I.P. Petrovskii], O znachenii krovnoi angliiskoi loshadi v russkom konnozavodstve, Moscow, 1850, p. 18.

${ }^{75}$ The Druid, Scott and Sebright, London, 1862, pp. 93-6, reprinted 'Baron Ippolyte Petroffski: The Celebrated Russian Turfite', New Sporting Magazine, May 1860, pp. 206-10. ${ }^{76}$ On Lunin, see Materialy, pp. 150-52. In 1853, 'Count Viacoff's' imports were widely reported in the English press: see, for example, Newcastle Courant, 22 Jul. 1853; Sporting Magazine, Aug. 1853, p. 151. V.A. Tropinin's 1842 portrait is in the Tret'iakov Gallery, Moscow.

${ }^{77}$ Quoted by N.A. Erofeev, Tumannyi al'bion: Angliia i anglichane glazami russkikh, 1825 1853, Moscow, 1982, pp. 83-4.
} 
George Taylor, ${ }^{78}$ who rode Lunin's bay colt, Arzas, to victory in the Imperial Prize for fouryear-olds - 'our St Leger' - narrowly beating John Gregory on Voeikov's Kredit. ${ }^{79}$ Five more English jockeys rode at the same meeting. One married Petrovskii's daughter; others, like Gregory, went on to manage their employers' stables. As Haxthausen discovered in 1843, the diminutive director of the Rostopchin stud in Voronezh province was 'a genuine offshoot of the Jockey Club' who showed off the four-year-old mares against a white wall: 'an Englishman of this class understands his business, and never loses sight of it' ${ }^{80}$ Herzen's cousin, D.P. Golokhvastov, prominent in Moscow racing circles, returned from Europe 'armed with plans of Devonshire farms and a Cornish stud stable and accompanied by an English riding-master' ${ }^{81}$ In 1854, the superintendent of the Mosolov stud near Moscow and one of its racing-grooms came from the celebrated Hampshire dynasty spawned by John Barham Day. ${ }^{82}$ Such men were valued for their expertise in handling the febrile animals at the heart of the English model. 'There is not the slightest doubt', Miasnov declared in 1833, 'that, as a result of their outstanding qualities, present-day English racehorses take precedence the whole world over: all opinions to the contrary are the consequence of onesided opinion and insufficient experience' ${ }^{83}$

\footnotetext{
${ }^{78}$ That same year, Taylor was reportedly hired as trainer and jockey by the Grand Duke Aleksandr Nikolaevich. See Nimrod, 'Foreign Sporting', New Monthly Magazine, 62, no. 245, May 1841, p. 51.

${ }^{79}$ Memnon Volunin [S.P. Zhikharev], Lebedianskiia skachki 1841 goda, n.p., n.d., signed Lebedian, 21 Sept. 1841, pp. 16, 7, 9-13. Memnon won the 1825 St Leger before joining Mosolov's stable; Volunin belonged to Zhikharev himself: see Materialy, p. 201. The St Leger is in fact a race for three-year-olds.

${ }^{80}$ Haxthausen, Russian Empire, 1, p. 380.

${ }^{81}$ Alexander Herzen, My Past and Thoughts, trans. Constance Garnett, 4 vols, London, 1968, 2, p. 567. See also, Materialy, pp. 40-46.

${ }^{82}$ See Simon Dixon, 'Allegiance and Betrayal: British Residents in Russia during the Crimean War', Slavonic and East European Review, 94, 2016, 3, pp. 445-46, and n. 71.

${ }^{83}$ Miasnov, O vospitanii skakovykh loshadei, p. 37.
} 


\section{The reaction against Anglomania}

A rival viewpoint nevertheless emerged with increasing force in the 1840s when the wider political climate favoured a purge of foreign impurities. British travellers had long condescended to nobles who recited their horses' English pedigrees 'through a list which their grooms have taught them, but which have no more real reference to their cattle than to the moon' ${ }^{84}$ Russians retorted with anthropomorphic national stereotypes. Kaznacheev welcomed Vorontsov's plans for cross-breeding because the 'morals' of the Crimean horses were essentially 'human' - 'you can do what you like with them' - whereas English horses were 'just as stubborn and strait-laced as the English themselves' ${ }^{85}$ The main challenge to English ways, however, came from the German tradition of scientifically-managed state studs, whose advocates criticized English racing's subservience to a fickle public. ${ }^{86}$

A vocal representative of this tradition in Russia was Ludwig Berghofer, founder of the Western Holstein Society for the Improvement of Horse-breeding in 1828 and a supporter of sturdy Danish breeds. Peppering his text with references to the latest German literature, Berghofer deplored the culture of English horsemen in 1844 as superstitious, secretive and incompetent thanks to their ignorance of veterinary science. But the nub of his criticism went deeper. The principal defect of the English model was that at best it could generate only highly-strung racers, built to sprint in a straight line over short distances. At worst, thanks to prevailing misconceptions about the relationship between racing and breeding, it threatened to flood the market with worthless hacks. No breed, Berghofer insisted, was so unsuited to Russia's needs as the English thoroughbred: its gait could never be adapted to dressage and parades and it lacked the strength required for military and civilian work. The Gatchina race

\footnotetext{
${ }^{84}$ Cross, 'By the Banks of the Neva', p. 20, quoting Edward Clarke, Cambridge's first professor of mineralogy, an 'unrelentingly vitriolic' critic of Russia: see ibid., pp. 308-10. ${ }^{85}$ Kaznacheev, Partikuliarnye pis'ma, p. 120 (20 Mar. 1832).

${ }^{86}$ Mitsuda, 'Horse in European History', pp. 115-47.
} 
of 1825 proved nothing: a true test of stamina could be achieved only by pitting at least a dozen English horses against a similar number of Russian breeds over even more punishing distances of up to seventy miles. Moreover, while Berghofer acknowledged that the wealthiest Russian owners had once been able to afford outstanding English horses, he warned that genuinely valuable animals were scarce. Since the descendant of a famous horse reached the market only after failing at the races, the unwary foreign buyer faced multiple pitfalls if he compounded his initial error by breeding from inadequate stock. ${ }^{87}$

Berghofer's claims were hard to refute, especially since most of them were accepted even by anglophiles. Miasnov had long since admitted the unsuitability of English horses for dressage. ${ }^{88}$ Nicholas I's preference for fattened parade horses merely compounded the problem. Early in the 1840s, Prince A.M. Dondukov-Korsakov saw thirteen overfed steeds collapse under the weight of their heavily-armed riders after trotting in the summer heat on manoeuvres near Ropsha. ${ }^{89}$ In England itself, criticism of horses bred purely for sport intensified over the century as commercial breeders switched from an emphasis on stamina in the early decades, when most provincial races were run in heats, to the need for speed after 1870, when the highest prizes went to sprints for two- and three-year-olds. ${ }^{90}$ Already in 1853 , Captain Louis Nolan, soon to perish in the charge of the Light Brigade at Balaklava, complained that 'the rules of our Turf encourage speed only', and found Russian mounts 'immeasurably superior in those qualities which constitute the true war-horse -- namely,

\footnotetext{
${ }^{87}$ Ludvig Berggofer, O konnozavodstve voobshche, i preimushchestvenno v Rossii, Moscow, 1845, esp. pp. 74-9, 90.

${ }^{88}$ P.N. Miasnov, O konskikh ristaniiakh i skakovykh loshadiakh, Moscow, 1824.

${ }^{89}$ A.M. Dondukov-Korsakov, 'Moi vospominaniia: 1840-1844 gg.', Starina i novizna, 5, 1902, p. 184.

${ }^{90}$ Vamplew, The Turf, p. 23.
} 
courage, constitutional vigour, strength of limb, and great power of endurance under fatigue and privation' ${ }^{91}$

In Russian races, where heats long remained the only way to fill a card from a small field, ${ }^{92}$ the seduction of aesthetics seemed particularly dangerous. From the start, racing in Moscow was urged as a way to counter the 'harmful' consequences of 'the British dealers' trade in defective horses from their own fatherland':

These dealers, taking advantage of a transient whim on the part of the majority of our breeders and satisfying it only in relation to horses' external appearance, are filling our studs with stallions and mares incapable of producing good stock. And, in truth, what sort of horses are English dealers ordering for sale? Either those recognized in England as incapable of issue, having produced only worthless offspring, or those unable to bear the pressures of preparation for races, or those that have already raced, but are completely exhausted by their excessive and protracted labours. ${ }^{93}$

There was reason in this. Memnon was offered to Mosolov only after an undistinguished stud career in England; Kirby ruthlessly sold on under-performers abroad. ${ }^{94}$ Since breeding was intrinsically risky, the history of English bloodstock in Russia unsurprisingly proved to be 'very chequered' ${ }^{95}$ Conscious that it was misleading to imply that English horses were automatically the best racers simply because they were classified first in the Russian stud-

\footnotetext{
${ }^{91}$ L.E. Nolan, Cavalry: Its History and Tactics, 3rd edn, London, 1860, p. 342. This passage was highlighted by the Illustrated London News, 3 Dec. 1853, p. 470.

${ }^{92}$ Horses which ran all four heats (32 miles) at Kherson were described as 'seldom fit for anything else after'. See 'Report on the Government of Kherson by Vice Consul George Alexander Stevens, 1859', TNA, FO 97/357, pp. 46-7: 'these Races are precisely as those in England, but the Jockies are inferior and beyond sitting on its back, do nothing towards aiding their Steed'.

${ }^{93}$ PSZ, 2nd series, vi, no. 4308, 31 Jan. 1831, 'Zapiska Maiora Maslova'.

94 'Mr Thomas Kirby, of York', New Sporting Magazine, Sept. 1857, p. 162.

95 The Druid, Silk and Scarlet, p. 148.
} 
book, the State Horse-breeding Board responded by removing all reference to such classifications from the third edition in $1848 .{ }^{96}$

By then, the Board had already embarked, following its amalgamation with the Ministry of State Domains, on a campaign to tackle the problems highlighted by Berghofer. With specialization in the state studs came a new emphasis on breeding and racing for agricultural purposes. Peasant cart-racing was initially such an impromptu affair that at St Petersburg in 1848 a shortage of weights required carts to be loaded with people instead. ${ }^{97}$ By 1849 , however, trials for peasant draughthorses were reported in twenty places from Estland to Ekaterinburg. ${ }^{98}$ Even critics acknowledged their popularity. Ivan Aksakov estimated that the 'stupid' cart races at the Iaroslavl' provincial fair in September 1850 attracted at least ten thousand people, including 'all the local bigwigs' ${ }^{99}$ At Simbirsk in July 1851, when the provincial governor presented the prizes, a Gypsy choir sang in front of stands for the judges and society ladies while Russian spectators mingled with colourfully-dressed Tatars, Chuvash, and Mordvins. The crowd peered through clouds of dust as Russian peasants drove to victory in cart races for five- to eight-year-olds, while Tatars, mostly riding bareback, triumphed in the open flat race after a jockey from the Mennonite colony at Saratov, eccentrically attired in a long black coat, had inadvertently led part of the twenty-six-strong field off the course, much to the spectators' amusement. All this was witnessed by Professor Unterberg of the Dorpat Veterinary School, who noted that the winner covered six versts (approximately four miles) in 8 minutes 43 seconds - 'a speed of which any English

\footnotetext{
${ }^{96}$ Zavodskaia kniga krovnykh i skakavshikh loshadei v Rossii, 3rd edn, St Petersburg, 1848, pp. X-xi.

${ }^{97}$ Rysistyi kalendar' svedeniia ob ispytaniiakh loshadei na rysistykh ippodromakh $v$ S. Peterburge i v Tsarskom Sele s 1845 po 1849 god, St Petersburg, 1849, p. 59.

${ }^{98}$ Otchet po Upravleniiu Gosudarstvennago Konnozavodstva za 1850 god (hereafter Otchet), 'Tabel' ob ispytaniiakh loshadei'.

${ }^{99}$ I.S. Aksakov, Pis'ma k rodnym, 1849-1856, ed. T.F. Pirozhkova, Moscow, 1994, p. 163 (11/23 Sept. 1850).
} 
racehorse would be proud' and 'all the more striking' because the three fastest runners 'were not prepared for the race as English racehorses are prepared, but are employed by their owners, crown peasants, as simple draughthorses'. ${ }^{100}$

Official disaffection with the English model was far from instantaneous. In 1847, the State Horse-breeding Board still insisted that England represented 'the outstanding example' of horses bred for both speed and stamina. Quoting the president of the Bavarian Economic Society to the effect that 'the strength of one English horse is equivalent to five Bavarian horses', the Board claimed that a similar ratio applied to Russia. ${ }^{101}$ This was the logic behind Major-General A.A. Bethancourt's visit to Britain to pay 17,129 silver roubles for twelve horses in 1850 , the year in which the Board's merger with the ministry was finally completed. ${ }^{102}$

That same year nevertheless signalled a pivotal change of direction. 'Until now', the Board reported, 'races in Russia have been run on the English model; but in recent times, all efforts in England, directed towards the achievement of speed alone [...] without attention to the capabilities necessary for conditions of service, have influenced the build and conformation of contemporary English thoroughbred breeds'. Determined to stem the proliferation of 'a mass of spoiled horses, useless for breeding', the Board restricted entrants for imperial prizes to four-year-olds and above and imposed normal minimum speeds on the French model, calculated against the previous year's averages in order to prevent a single

\footnotetext{
${ }^{100}$ Izvestiia iz vnutrennykh gubernii Rossii, preimushchestvenno dlia liubitelei loshadei: Otchet professora Derptskago veterinarnago uchilishcha kollezhskago sovetnika Feodora Unterberga, o poezdke sovershennoi im vo vremia letnikh vakatsii v 1851 om godu, Dorpat, 1854, 73.

${ }^{101}$ Statisticheskoe obozrenie, pp. 2-3, quoting Joseph, Ritter von Hazzi.

102 Otchet za 1850 god, pp. 9-10. The Board entrusted the purchase of Arab horses to the Russian consul in Beirut, K.M. Bazili, better known for his protection of Russian pilgrims in the Holy Land.
} 
feeble runner from taking a prize unopposed. ${ }^{103}$ Despite the resentments provoked among private owners, the authorities noted with satisfaction that almost two-thirds of the prizemoney in 1851 went to horses sired by state-owned stallions following the government's purchase of Orlov's Khrenovo stud. This, the ministry claimed, constituted 'new proof' of the benefits conferred on private breeders by the state. It was true that the number of runners had dropped from 121 in 1850 to 79 in 1851 , but this fall was ascribed to the 'notable development' of harness-racing, 'which offers more material gains to breeders, through the annual rise in value of trotting horses'. Whereas the state studs sold 8,487 riding horses between 1841 and 1857 at an average price of 70 silver roubles, the average for a Khrenovo trotter stallion was more than ten times higher. Trotting departments also outperformed riding departments in mixed private studs and participation in trotting races rose by 79 to 198 between 1850 and $1851 .{ }^{104}$ Indeed, the 1840 s and 1850 s marked the golden age of the Orlov trotter and the emergence of a distinctive racing culture to trial the breed.

\section{Russian harness-racing and the Orlov trotter}

Foreigners repeatedly noted the nobility's obsession with fast and elegant sledge and carriage horses. The artist Robert Ker Porter, resident in Russia between 1805 and 1807, admired 'slight and Arabic' trotters 'possessing the grace of an Italian greyhound with a peculiar lightness and looseness of pace'. ${ }^{105}$ Orlov's breed, though larger, was equally nimble. To the Essex doctor, John Salter, who made nine trips to Russia between 1898 and 1912 to judge dog shows on behalf of the Kennel Club, the Orlov trotter was 'a wonderful animal': 'His

\footnotetext{
${ }^{103}$ Ibid., pp. 23-6. For changing norms at Novocherkassk and Uriupinsk, where Don Cossack officers raced fully armed, see PSZ, 2nd series, xxvii, no. 26380 (16 June 1852); xxxi, no. 30614 (18 June 1856).

104 Otchet za 1851 god, pp. 21-4; Vitt, Iz istorii russkogo konnozavodstva, pp. 333-34.

${ }^{105}$ Robert Ker Porter, Travelling Sketches in Russia and Sweden during the Years 1805, 1806, 1807, 1808, 2 vols, London, 1809, 1, p. 110.
} 
action is very high, his going very clean and fast. He is very much on the big side, most of their males being over seventeen hands.' Told that many were worth $£ 500$ apiece, Salter described the six pairs shown off to him by a Moscow banker as 'such a sight as I shall never see again'. ${ }^{106}$ The Irish veterinarian, Captain Horace Hayes, was more sceptical:

With inherited trotting faculty, long legs, and light and short body, many of them can trot at a great pace, but they are poor stayers. They admirably suit the requirements of fashionable Russians, who love to go as fast as their coachmen can drive them, even over the roughest cobble stone pavement, which of course does not suit the big fetlocks. They rarely stand more than a couple of years of this kind of work, and then they gradually descend towards the cab rank. ${ }^{107}$

In the trotter's heyday, debates in the Russian breeders' journal overflowed into the newspapers. According to Koptev, who eulogized Orlov's creation in Moskovskiia vedomosti, English racehorses and Dutch draughthorses stood at opposite ends of a spectrum in which Arabs represented the golden mean. Just as foreigners, including the English, had bred distinctive strains from Arab stock to suit their respective national needs and climates, so Orlov had developed a strong but frisky animal ideal for Russian conditions. Resembling an Arab horse 'seen through a magnifying glass', the Orlov trotter was the perfect animal for breeding. ${ }^{108}$

Contemporaries agreed, competing to buy, breed and trial horses descended from Orlov's treasured stock. Harness-racing was introduced at Lebedian in 1832, four years

${ }^{106}$ Dr. Salter of Tolleshunt d'Arcy in the County of Essex, Medical Man, Freemason, Sportsman, Sporting-Dog Breeder and Horticulturalist: His Diary and Reminiscences from the Year 1849 to the Year 1932, ed. J.O. Thompson, London, 1933, p. 349, undated memoir. ${ }^{107}$ Capt. M. H. Hayes, Among Horses in Russia, London, 1900, p. 67. 108 [Vasilii Koptev], O porodakh loshadei voobshche, $i$ v osobennosti o skakovoi i rysistoi (Pis'mo k P.P. V[oeiko]vu), Moscow, 1849, pp. 8, 16. On the Orlov trotter, start from Vitt, Iz istorii russkogo konnozavodstva, pp. 185-279. Sales of the breed in England were apparently limited: for a rare advertisement for a six-year-old Khrenovo bay stallion, 15 hands 2 inches, see York Herald, 15 Jan. 1848, p. 8. 
before the first official French races at Cherbourg. Further provincial societies followed at Voronezh in 1836 and in 1837 at Tambov, where that autumn a rare English visitor found trotting 'greatly in vogue' and saw highly-priced animals -- 'large and showy, like London cabriolet horses' -- training on the racecourse adjoining the horse-fair. Following the growing fashion, Kozlov, a district town in Tambov province, had its own trotting society by $1841 .{ }^{109}$ At the society established in Moscow in 1834, an expanded three-track hippodrome was constructed from 1843 , overlooked by a pavilion opened five years later. ${ }^{110}$ In 1845 , harnessracing began at Tsarskoe Selo, proving popular there and, from 1846, in the capital, where improved speeds, meticulously recorded in racing calendars, generated copy for journalists keen to stimulate rivalries between Moscow and St Petersburg. ${ }^{111}$ The first trotting stud-book inevitably followed. ${ }^{112}$ Further societies were established at Khar'kov and Penza in 1848 and at Orel in $1851 .{ }^{113}$ By then, a growing band of enthusiasts had had their favourite horses immortalized by Nikolai Sverchkov, who toured the provincial studs in the 1840s having launched his career as Russia's leading animal painter as artist-in-residence at Khrenovo. ${ }^{114}$

Unlike thoroughbred-racing, trotting offered a winter season, calendared in the breeders' journal at Moscow (from 1845), Penza (1849), Simbirsk (1856) and Tambov (1860). When ice-racing began in St Petersburg in 1846, at hippodromes constructed opposite

${ }^{109}$ PSZ, 2nd series, xi, no. 9064 (7 Apr. 1836); xii, no. 9984 (2 Mar. 1837); xvi, no. 14635 (10 June 1841); Rev. R. Lister Venables, Domestic Scenes in Russia, London, 1839, p. 150. ${ }^{110}$ D.D. Sontsov, Al'bom piatidesiatiletnego iubileia Moskovksago obshchestva liubitelei konskago bega, 1834-1884, Moscow, 1884, pp. 25-6; L. A. Velikhov and A.A. Krasovskii, Istoricheskii ocherk deiatel'nosti Imperatorskago S.Peterburgskago Obshchestva Pooshchreniia Rysistago Konnozavodstva 1861-1911, St Petersburg, 1911, pp. 24-6. ${ }^{111}$ Rysistyi Kalendar' ... s 1845 po 1849 god, pp. 79-93; Rysistyi Kalendar' ... v 1849 godu, St Petersburg, 1850, pp. 56-68; Moskvitianin, Apr. 1850, 'Smes', p. 83; ibid., Aug. 1850, 'Smes', pp. 40-42.

112 Zavodskaia kniga vyigravshikh i bezhavshikh loshadei na rysistykh begakh v Rossii, St Petersburg, 1847. ${ }^{113}$ PSZ, 2nd series, xxiii, no. 21940 (27 Jan. 1848).

${ }^{114}$ N.V. Shaposhnikova and D.Ia. Gurevich, Nikolaï Egorovitch Svertchkov, le peintre russe du cheval 1817-1898, Lausanne, 2000. 
the Winter Palace on the frozen Neva, the rivalry between breeds was as intense as ever. In 1850, an English correspondent noted with interest, a team of 'ordinary Russian horses' defeated the racing stallions entered in the troika competition by Prince Menshikov. ${ }^{115}$ The imperial prize ice-race of 1859 was commemorated by an expensive engraving, captioned in both Russian and French and emblazoned with the imperial coat of arms to indicate the patronage of Grünewaldt and the State Horse-breeding Board (see Fig. 1). From January 1861, such contests were organized by a new society, founded by the capital's foremost trotting enthusiasts, including Grünewaldt himself. While spectators of various ranks climbed onto their carriage seats for a better view, the society's guests occupied a traditional pavilion -- 'if it be a privilege to remain immobile in the freezing cold in an open gallery', as a visiting Frenchman remarked. ${ }^{116}$ At Kazan', where winter races began in 1867, they were to be abandoned only in a snowstorm or if the temperature dropped below 18 degrees of frost. ${ }^{117}$

To English eyes, the spectacle seemed tame. Reporting on the 1868 season in $\mathrm{St}$ Petersburg, run on Sunday afternoons from early January to late March, one journalist complained that, except in the case of troikas, which started in line, there was 'little to interest the spectators'. Since other entrants, starting on different sides of the course, went off in opposite directions and spent much of the contest hundreds of yards apart, there was 'nothing corresponding to the excitement of a neck and neck race'. ${ }^{118}$ Nevertheless, he had to

${ }^{115}$ Morning Post, 10 May 1850, p. 6, 'The Horses of Russia'.

116 Zhurnaly zasedanii Obshchestva okhotnikov konskago zimnego bega: $S 10$ dek. 1860 g. po 21 Apr. 1883 g., St Petersburg, 1911; Théophile Gautier, Voyage en Russie, 2 vols, Paris, 1867, 1, pp. 193-208 (p. 199). Russia's National Electronic Numismatic Archive exhibits two of the society's medals, awarded in 1865 to Grünewaldt and in 1872 to Prince V. D. Golitsyn: see, respectively, https://numar.ru/medals/aleksandr-ii/persony/prices3477 and https://numar.ru/medals/aleksandr-ii/persony/prices3555 [accessed 3 June 2020].

${ }_{117}$ PSZ, 2nd series, xlii, no. 44743, para. 153 (2 June 1867).

118 Standard, 2 Apr. 1868, p. 5. Beyond Aintree, from 1839, and Manchester's Belle Vue stadium, opened in 1846, harness-racing made little impact in Britain. See, 'Neobvyknovennyi rysistyi beg v Manchestere', Zhurnal konnozavodstva, Dec. 1847, p. 1246. 
admit that, despite the lack of betting, ice-racing was popular among all classes, who not only lined the course but thronged the quay outside the Winter Palace. Any lack of speed was compensated by arcane regulations designed to ensure intricacy of performance.

Unexpectedly invited to judge the summer trotting races at Riazan' in 1852, Count M.D. Buturlin considered himself just as competent to decide the Academy of Sciences' prize for Chinese literature. ${ }^{119}$ For owners, however, the clearest advantage of trotting over flat-racing and steeplechasing was that it combined a more affordable entry level with the prospect of pecuniary gain from a rising market. Although often no more than a mirage, that prospect was sufficient to tempt hundreds of participants.

Buturlin's connection with horses came through his cousin, Major-General N.A. Divov, whose fanatical commitment to his trotting stud, founded at Gorodische in Riazan' province in 1850, was characteristic of an emergent group of novice breeders. The overwhelming majority of the studs registered in Graevskii's 1854 compendium had been founded since $1830 .{ }^{120}$ While thoroughbred-racing was dominated by plutocrats - it was ironic that Miasnov, the most ardent anglophile, could never afford an English jockey trotting attracted the next social rung down. As an honorary member of the Lebedian racing society, Divov could trace personal links to Orlov-Chesmenskii, whose funeral he had attended as a youth, ${ }^{121}$ and was friendly with Count A.F. Orlov, head of the Third Section, whose typography printed the leading racing calendars. Aristocrats also invested in trotting: Prince N.N. Gagarin's stud at Petrovskoe was a flourishing mixed operation. ${ }^{122}$ But, like Divov, Gagarin, who raced trotters at St Petersburg from 1848, had served in the cavalry.

\footnotetext{
${ }^{119}$ Zapiski grafa M.D. Buturlina, 2 vols, Moscow, 2006, 2, p. 196. See, for example, Ustav moskovskago obshchestva okhotnikova konskago bega 1851 goda, Moscow, 1852.

${ }^{120}$ N. Graevskii, Rysistye zavody v Rossii, sostavlennye iz opisei vladel'tsev zavodov, St Petersburg, 1854.

${ }^{121}$ The Russian Journals of Martha and Catherine Wilmot, 1803-1808, eds the marchioness of Londonderry and H.M. Hyde, London, 1935, p. 315, Martha's journal (9 Jan.1808 N.S.). ${ }^{122}$ Statisticheskoe obozrenie, p. 105; Graevskii, Rysistye zavody, pp. 197-237.
} 
And it was cavalry officers who dominated harness-racing, a point which militates against any exaggerated contrast between 'riding' and 'driving' cultures. ${ }^{123}$ Divov was drawn into breeding by his neighbour, Major-General A.A. Boldyrev, and at least fifty-three of the ninety-five trotting studs whose ownership could be established by Graevskii belonged to military men. ${ }^{124}$

Although Graevskii listed only one non-noble owner - the Moscow merchant, Vasilii Shanin, whose Voronezh province stud dated from 1830 - even his 1500-page tome accommodated only the cream of Russia's trotting establishments; merchants had participated in harness-racing since the era of Orlov-Chesmenskii. ${ }^{125}$ At St Petersburg and Tsarskoe Selo, the owners' social composition ranged wider than the clutch of aristocrats and generals who dominated the racing committees. And in the central black-earth region, where statisticians noted in 1851 that even the poorest landowners kept 'several mares (which they pretentiously call a stud)', the social reach of harness-racing was deeper still. ${ }^{126}$

The result was a distinctive culture that snobs found alien and corrupt. As Prince D.D. Obolenskii later recalled:

Whereas the aristocratic element predominated in racing societies, in the trotting pavilion I was always struck by the mass of dealers, gypsies and people having nothing in common with sport [understood as cultured expertise, rather than mere competition]. Of course, there were also very many agreeable and educated people perhaps they even comprised the majority of the membership - but they somehow retired into the background and dealers and loud-mouths (krikuny) played the

\footnotetext{
${ }^{123}$ Mitsuda, 'Horse in European History', overstates this binary, though some cavalrymen, including V.A. Norov, did privilege riding over driving: see Materialy, p. 118. ${ }^{124}$ Graevskii, Rysistye zavody. On Boldyrev's studs, see Materialy, pp. 27-35. ${ }^{125}$ Graevskii, Rysistye zavody, pp. 780-826; Zhikharev, Zapiski, 1, p. 49 (12 Feb. 1805). ${ }^{126}$ Voenno-statisticheskoe obozrenie Rossiiskoi Imperii, 17 vols, St Petersburg, 1848-58, 13, part 1 (Tambov province), p. 68, original emphasis.
} 
dominant role: enthusiasts who had apparently taken the sport of trotting into their own hands. ${ }^{127}$

Unterberg claimed that Pferdeverschönerungskunst (the art of beautifying a horse) was one field in which Russians could take pride in their backwardness: such nefarious practices as filing a horse's teeth to make it look younger - a swindle the English called 'bishoping' were largely confined to Gypsies, Tatars and Jews. Though the Ministry of State Domains echoed this widespread allegation, Russians themselves were no strangers to cheating. ${ }^{128}$ The first advice-book about fraudulent horse-dealers had been published in $1778 .{ }^{129}$ And Mikhail Stakhovich's three-act comedy Naezdnikov (1854) confirms that trotting was renowned as a paradise for the unscrupulous. The action revolves around a drink-sodden dealer, Shelokhvastov, who complains that whereas it had once been simple to dupe a gullible customer, more elaborate ruses were required now that 'any milksop' could buy the studbook. Shelokhvastov proceeds to sell a one-eyed horse to a credulous young landowner prepared to pay an inflated price having been seduced by the nag's fictional pedigree and by the dealer's meretricious recourse to French and Latin:

Bogachevskii (the landowner): Now Mr Professor! What sort of -ology is that? Phrenology or psychology ... Something like that. Is there [such a thing as] horse-ology?

Shelokhvastov: It's hippology ...

${ }^{127}$ Quoted in Krivoshein, Lebedianskoe skakovoe obshchestvo, p. 94.

${ }^{128}$ Unterberg, Izvestiia, p. 64; Zhurnal Ministerstva Gosudarstvennykh Imushchestv, 55, part 3, 1855, p. 87. On Gypsies, P. Vistengof, Ocherki moskovskoi zhizni. Moscow, 1842, p. 169. On bishoping, Frederick Taylor, Confessions of a Horse Dealer, London, n.d. [1857], pp. 3033.

${ }^{129}$ Sovershennoe i pravil'noe opisanie o svedenii konskikh statei i dostoinstv po naruzhnomu ikh vidu s tochnym i reshitel'nym ob"iasneniem vsekh obmanov upotrebliaemykh pri prodazhe konskimi baryshnikami, St Petersburg, 1778. 
Bogachevskii: Well, of course, you're a hippologist! ${ }^{130}$

As reviewers remarked, Stakhovich's play might not have been a literary classic but it captured to perfection the seamy atmosphere of the Russian horse world. ${ }^{131}$

\section{Zenith}

Judging from the evidence of the breeders' journal, that world was but little disrupted by the

Crimean War. Racehorses and hunters were excluded from the ban on horse exports imposed by neutral Prussia and racing continued undisturbed, not only in the two capitals, but also across much of the central black-earth region. ${ }^{132}$ After the war, the Russian debate about English horses raged on, even as anxieties emerged in Britain itself about the deterioration of native thoroughbreds in the face of foreign competition. ${ }^{133}$ In a virulent critique of the Orlov trotter, a contributor to Russkii vestnik, the most anglophile of the Russian periodicals under the editorship of Mikhail Katkov, rehearsed the virtues of the English model in 1860 arguing that 'the introduction of the English thoroughbred would swiftly elevate the studs in the Don'. He acknowledged, however, that the region's inhabitants would not be easily persuaded. ${ }^{134}$ And indeed a military survey of Kherson province soon claimed that breeders there had 'made a big mistake at the start and ruined their studs by using English stallions

\footnotetext{
${ }^{130}$ Mikhail Stakhovich, Naezdnikov, Moscow, 1854, p. 47. Stakhovich (1820-58), who inspired Tolstoy's story, 'Kholstomer' ['Strider'], seen through the eyes of an ageing piebald gelding, was murdered by thieves on his estate.

${ }^{131}$ Otechestvennyia zapiski, 97, 1854, no. 12, 'Bibliograficheskaia khronika', pp. 90-94.

132 TNA, FO 64/393, Bloomfield to Clarendon, Berlin, 25 May 1855. On Moscow’s wartime harness-races, see Materialy, pp. 291-310.

133 [T. Erskine Perry], 'English Horses', Edinburgh Review, Jul. 1863, pp. 116-24, 131, 144 46 , attributed the 'profusion of weedy animals' to too many sprints for immature horses and the predominance among breeders of greedy smallholders rather than affluent gentry.

${ }^{134}$ D. Ivanov, 'Sovremennoe sostoianie konnozavodstva v Rossii', Russkii vestnik, Jul. 1860, p. 235.
} 
when they should have used Arab ones. Now many of them have realized this and are trying to obtain stallions from the East'. ${ }^{135}$

Against this disputatious backdrop, Russian horse-racing seemed to flourish as never before. The Riazan' racing society was authorized for a second decade in December 1856; that at Lebedian was renewed in perpetuity in the following autumn. In 1858 a new society opened in Vil'no on the customary expectation that it would promote 'the perfection of horsebreeding'. ${ }^{136}$ The prospects for trotting seemed just as rosy. In the final weeks of the Crimean War, a harness-racing society was founded at Elets in Tambov province, where races coincided with the September horse-fair, conveniently timed between meetings at Voronezh and Lebedian. More societies soon followed at Vladimir in July 1856 and at Saratov, Smolensk and Ekaterinoslav in 1858, the year in which the second edition of the trotting studbook appeared. ${ }^{137}$

Anyone who doubted the industry's vitality had only to visit the noble estates whose stables made a powerful visual impression. The Swiss architect Domenico Gilardi had led the way by transforming Khrenovo into a monumental palace in the Empire style between 1820 and 1832. At Prince S.M. Golitsyn's estate at Kuzminki near Moscow, Gilardi designed a vast neo-classical ensemble across the lake from the house. The pillared entrance hall to the stable courtyard doubled as a music pavilion, its doors framed, from 1846, by two rearing bronzes done by Baron Peter von Clodt in the manner of his celebrated 'Horse Tamers' on St Petersburg's Anichkov Bridge. Horses on the Golitsyn estate at Trostianets in Poltava

\footnotetext{
${ }^{135}$ Materialy dlia geografii i statistiki Rossii, sobrannye ofitserami General'nago Shtaba: Khersonskaia guberniia, chast' vtoraia, St Petersburg, 1863, p. 201. ${ }^{136}$ PSZ, 2nd series, xxxi, no. 31204 (2 Dec. 1856); xxxii, no. 32265 (8 Oct. 1857); xxxiii, no. 33250 (4 June 1858); Ustav Vysochaishe utverzhdennago vilenskago skakovago obshchestva, Vil'no, 1858, pp. 3-4, para. 2.

${ }^{137}$ Krivoshein, Lebedianskoe skakovoe obshchestvo, p. 135; PSZ, 2nd series, xxxi, no. 30194 (20 Feb. 1856); no. 30671 (2 Jul. 1856); xxxiii, no. 33433 (8 Aug. 1858); no. 33629 (18 Oct. 1858); no. 33710 (2 Nov. 1858); Zavodskaia kniga vyigravshikh i bezhavshikh loshadei na rysistykh begakh v Rossii, 2nd edn, St Petersburg, 1858.
} 
province performed in a coliseum built in the Muscovite style from $1749 .{ }^{138}$ A century later, Haxthausen discovered that Orlov was building a stud-house at Pady for 500 mares. Since the façade was 600 yards long, it was perhaps not merely prudent respect for Russia's leading secret policeman that caused Unterberg to praise Pady as the finest stud he had seen. The walls of its spacious manège were decorated with Orlov's coat-of-arms; horse-head bronzes on the doors were covered by retractable cloth cylinders to protect the animals while exercising. ${ }^{139}$ Though few could compete with such opulence, there was still apparently a market for architects in 1859, when Aleksandr Kutepov's plans to suit various budgets, first published in 1840, were re-issued four years after his death (see Figs $2 \& 3$ ). ${ }^{140}$ At Lesishche in Riazan' province, Boldyrev invested his gambling gains in a 'foppish stable' boasting 'a large salon, with fireplaces, where horses could be exercised in front of potential purchasers'. ${ }^{141}$ Koptev published a glowing account of neighbouring Gorodishche, where the stables outclassed the residence, a cross between a medieval Russian dwelling and a Swiss chalet embellished with a brick minaret (still extant) in homage to Divov's visit to Constantinople in 1848. It was 'impossible to imagine more comfortable or better planned accommodation', Koptev assured readers of the breeders' journal in 1859: 'Everything is arranged in proportion, spaciously, peacefully [...] Water is supplied to each stall, and the groom has only to turn on a tap to allow a horse to drink fresh water'. ${ }^{142}$

\footnotetext{
${ }^{138}$ E. Beletskaia, D.I. Zhiliardi, Leningrad, 1980, pp. 92-8, 102-5; Priscilla Roosevelt, Life on the Russian Country Estate: A Social and Cultural History, New Haven, 1995, pp. 130, 13233.

${ }^{139}$ Haxthausen, Russian Empire, 1, p. 378; Unterberg, Izvestiia, pp. 93-4. Orlov also built a neo-gothic stable (now derelict) on his Strel'na estate.

${ }^{140}$ A. Kutepov, Fasady i plany stroenii koniushen dlia loshadei verkhovykh $i$ upriazhnykh $i$ koniushen dlia konskikh zavodov, Moscow, 1859.

${ }^{141}$ Zapiski Buturlina, 2, p. 179 (1852).

${ }^{142}$ Materialy, p. 5; Zapiski Buturlina, 2, p. 145; Irina Gracheva, 'Divo v Divove', in P.V. Akul'shin (ed.), Riazanskie usad'by i ikh vladel'tsy, Riazan', 2006, p. 115.
} 
There could hardly have been a sharper contrast between the clean, well-ventilated stables occupied by the nobility's prize horses and the hovels inhabited by their peasants. But the tables were already being turned even before serf emancipation finally exposed unsustainable noble expenditure on both breeding and racing. Although it suited contemporaries from different ends of the political spectrum to portray the emancipation as a cliff-edge catastrophe for the noble economy, ${ }^{143}$ the writing was on the wall for the Russian horse industry long before 1861.

\section{Nadir}

While we now know that many nobles stayed solvent by limiting their outlay and scheduling manageable levels of debt across labyrinthine networks of personal credit, neither aspiration was easily achieved by those obsessed with horses. The young wastrel Count D.N. Tolstoi had to be bailed out by his father after accumulating obligations of 30,000 roubles on furs and a string of pedigree animals, some of which proved worthless when he went bankrupt in 1863. ${ }^{144}$ By then, problems facing breeding and racing extended far beyond the sphere of personal profligacy. Between 1823 and 1859, noble indebtedness to the state had increased by an annual average of 9.3 million roubles. And since 88 per cent of government loans went to owners of more than 100 serfs, medium-scale stud-farmers were sure to be vulnerable when the collapse of the state banks in 1859 left them bereft of institutional credit. ${ }^{145}$ For the first time since its launch, the breeders' journal failed to appear in December 1859. Though

\footnotetext{
${ }^{143}$ On Smolensk province, 'Pis'ma 1863 goda' in A.N. Engel'gardt, Iz derevni: 12 pisem 1872-1887, ed. A.V. Tikhonova, St Petersburg, 1999, pp. 480-81; on Ekaterinoslav province, V.P. Meshcherskii, Pis'ma k velikomu kniaziu Aleksandru Aleksandrovichu 1869-1878, ed. N.V. Chernikova, Moscow, 2014, pp. 149-52 (10 Jul.1869).

${ }^{144}$ Sergei Antonov, Bankrupts and Usurers of Imperial Russia: Debt, Property, and the Law in the Age of Dostoevsky and Tolstoy, Cambridge, MA, 2016, esp. pp. 82-89, 107. ${ }^{145}$ Ibid., pp. 29, 91-92, 339, n. 105; Steven L. Hoch, 'The Banking Crisis, Peasant Reform, and Economic Development in Russia, 1857-1861', American Historical Review, 96, 1991, 3, pp. 795-820, esp. p. 804.
} 
details remain sparse, it seems clear that noble investment in horses ranked among the first casualties of the years immediately before and after the emancipation. According to one widely-touted estimate, more than a thousand Russian studs, roughly 40 per cent of the total, closed between 1857 and $1864 .{ }^{146}$ It was no surprise that the Sheremetevs should have sold Serebrianye prudy, which never produced its own breed, since its incipient decline had been noticed a decade earlier. ${ }^{147}$ Koptev was nevertheless dismayed to report the wider devastation in his native Tula province where a string of high-profile trotting studs had 'disappeared without trace' by $1865 .{ }^{148}$ It was a similar story across the central horse-breeding area. The compiler of a new multi-volume survey, published in the 1870s, found that many such studs had closed and still more belonged to new owners who ignored his requests for information. ${ }^{149}$

Change on such a scale was bound to damage racing. From Kherson, the British viceconsul reported in 1859 that the October races established by Vorontsov were now 'both badly managed and attended, though every exertion was made by the present Governor during the last two meetings to interest the public in them'. ${ }^{150}$ No member of the Lebedian racing society attended the 1859 meeting and only nugatory sport was reported in the following year. Racing had been discontinued by 1862, when Lebedian had already entered a spiral of decline that saw turnover at its Pokrovskaia fair collapse from 5000 head in the

\footnotetext{
${ }^{146}$ D. Dubenskii, Istoricheskii ocherk razvitiia Russkago Gosudarstvennago i chastnago konnozavodstva ot Moskovskoi Rusi i do nashikh dnei, St Petersburg, 1896, p. 36. See also, 'Vedomost' o sostoianii chastnykh konskikh zavodov, s 1859 po 1864', Zhurnal konnozavodstva, May 1865, appendix.

${ }^{147}$ Voenno-statisticheskoe obozrenie, 6, part 4 (Tula province), p. 76; Vitt, Iz istorii russkogo konnozavodstva, pp. 134-36.

${ }^{148}$ Materialy, pp. 114-16.

${ }^{149}$ N. Lodygin, Kniga rysistykh loshadei v Rossii s opredeleniem chistoporodnosti, vol. 5 , Moscow, 1871, pp. 178, 189, 228.

${ }^{150}$ TNA, FO 97/357, p. 46 (G.A. Stevens, above, n. 92).
} 
1850 s to only 300 by $1891 .{ }^{151}$ Further failures ensued. The Vladimir trotting society folded in 1865; Orel's closed in 1867, swiftly followed by those at Ekaterinoslav and Riazan'. ${ }^{152}$

Koptev believed that harness-racing survived at Tula thanks only to the society's recruitment of local merchants. ${ }^{153}$ The Moscow-Tula railway probably hastened the permanent transfer of Tula's thoroughbred races to Moscow in 1866. The line from Moscow to Riazan', opened in 1864 and extended to Kozlov in 1866 and Tambov in 1869, similarly increased the centripetal attraction of the capitals' trotting hippodromes. ${ }^{154}$

Though contemporaries complained that provincial racing was fatally damaged by the restriction of imperial prizes to Moscow and Tsarskoe Selo from January $1860,{ }^{155}$ prizemoney had always been an incentive rather than a subsidy. So long as fields remained small rarely more than six and sometimes as few as two - most owners could anticipate mediumterm gains from prizes that boosted both the value of individual winners and the prestige of their stables as a whole. By 1860, winners of imperial trotting prizes could fetch as much as 10,000 silver roubles. However, the monetary value of most prizes was negligible, particularly for places in minor races, and blue ribands were the preserve of a select few. The same Europe-wide pattern persisted under the tote. In the 1894 harness-racing season, for example, although some 120 owners won at least a thousand roubles, 8.5 per cent of Russia's total prize-money $(61,208$ r. out of 728,733 r.) went to a single nobleman, N.M. Konoplin, a

\footnotetext{
${ }^{151}$ Krivoshein, Lebedianskoe skakovoe obshchestvo, p. 143; Ivan Merder, Sbornik svedenii o torgovle loshad'mi v Rossii, St Petersburg, 1891, p. 87.

${ }^{152}$ PSZ, 2nd series, xl, no. 42426 (25 Aug. 1865); xlii, no. 44166 (24 Jan. 1867); xliii, no. 45799 (4 May 1868).

${ }^{153}$ Materialy, p. 480.

${ }^{154}$ J.N. Westwood, A History of Russian Railways, London, 1964, pp. 43, 67.

${ }^{155}$ Krivoshein, Lebedianskoe skakovoe obshchestvo, p. 146. The Board continued to award its own prizes, amounting in 1875 to 50,550r. for thoroughbreds and 21,900r. for trotters: Pamiatnaia knizhka po Glavnomu Upravleniiu Gosudarstvennago Konnozavodstva na 1875 g., St Petersburg, 1875, p. 41.
} 
Tambov breeder who dominated the Moscow hippodrome before the First World War. ${ }^{156}$ As a Russian historian of French horse-racing commented, even generous state prizes could fund only the most minor of studs. ${ }^{157}$ The same was true in Russia. To enthusiasts such as Petrovskii, whose stable raced as far apart as St Petersburg, Moscow, Tula and Lebedian, prize-money scarcely covered travel expenses.

We should be equally cautious about overstating the significance of breeders' access to state-owned stallions. It is true that, of the local authorities (zemstva) established in 1864, only those at Vil'no and Perm elected to maintain these benefits when the state withdrew them. ${ }^{158}$ Though enterprising owners could borrow stallions from friends - Afanasy Fet relied on Ivan Turgenev, who had attended the Epsom Derby in 1857 and set one of his Sportsman's Sketches at Lebedian ${ }^{159}$ - small studs were doubtless afflicted. Some indication of the gap to be filled comes from the General Staff survey conducted between 1847 and 1853. According to the exceptionally detailed account of Orel province, at least twenty-six of the 103 listed studs reported regular or occasional recourse to state-owned stallions. Such sires were nevertheless intended primarily to improve peasant rather than noble horsebreeding, and most surveyors stressed that they did so. Only a handful of studs in each province were declared profitable. Most, by contrast, were reported as 'in decline', retarded by shortage of pasture (converted to arable as the population grew), the high price of oats and the low market value of all but the most exceptional horses. ${ }^{160}$ The surveyors' verdict was

\footnotetext{
${ }^{156}$ Calculated from Rysistyi kalendar' 1894 goda, St Petersburg, 1895, pp. 1007-10. For a comparable distribution, see Skakovoi kalendar' 1894 goda, St Petersburg, 1895, pp. 859-62. See also, L.N. Bocharov, Dvadtsatipiatiletie sportivnoi i konnozavodskoi deiatel'nosti Nikolaia Mikhailovicha Konoplina 1886-1911, Moscow, 1911.

${ }^{157}$ Kniaz' A.N. Orlov, Konevodstvo i konnozavodstvo v Frantsii, 3 vols, St. Petersburg, 1900, 3, pp. 83-90.

${ }^{158}$ PSZ, 2nd series, xxxix, no. 40489 (14 Jan. 1864).

${ }^{159}$ A.A. Fet to V.P. Botkin, 21 Feb./5 Mar. 1865, in A.A. Fet i ego literaturnoe okruzhenie, ed. T.G. Dinesman, Literaturnoe nasledstvo, 103, book 1, Moscow, 2008, p. 402.

${ }^{160}$ Voenno-statisticheskoe obozrenie, 6, part 5 (Orel province), pp. 83-92. Revealing surveys include ibid., 5, part 1 (Simbirsk), pp. 81-95; 6, part 2 (Vladimir), pp. 192-94; 6, part 3
} 
echoed by Ivanov in 1860. Despite the 'amazing' number of studs in Russia and the swelling ranks of equestrian enthusiasts, breeding, like racing, remained what it had always been: not so much a business as a ruinous pastime. ${ }^{161}$ In retrospect, stud-owners agreed that many had been sustained only by a supply of specialist unfree labour - inarticulate sporting equivalents of the serf actors, musicians and artists who have attracted more notice from historians. ${ }^{162}$ When the market for noble riding- and carriage-horses collapsed in 1861, Russia's serf jockeys and grooms found more lucrative employment elsewhere. ${ }^{163}$

\section{Revival}

Crisis, however, did not signal terminal decline. Many lesser nobles adapted by selling their estates to aristocratic entrepreneurs whose portfolios were bolstered by industrial and urban investments. Stud-farms followed a similar trajectory, much as they did in England, where commercial breeders increasingly supplanted small-scale gentry studs from the 1870 s. ${ }^{164}$ Founded in 1859 by Count I.I. Vorontsov-Dashkov - the eighth greatest serf-owner in Russia - the Novotomnikovo stud still flourishes near Morshansk in Tambov province, where a harness-racing society opened in 1865 even as others were folding. ${ }^{165}$ Provided that their owners responded to the new conditions, lesser studs could also survive. After retiring from the cavalry, Fet devoted himself to stud-farming in Orel province where he proved adroit at

(Riazan'), p. 33; 12, part 3 (Poltava), pp. 65-7. On conversion of pasture to arable, see David Moon, The Russian Peasantry 1600-1930: The World the Peasants Made, Harlow, 1999, p. 139.

${ }^{161}$ Ivanov, 'Sovremennoe sostoianie konnozavodstva', p. 245, above, n. 134.

162 Richard Stites, Serfdom, Society and the Arts in Imperial Russia: The Pleasure and the Power, New Haven, 2008.

${ }^{163}$ For conversation on these topics at the 1866 All-Russian Horse Show, see Materialy, p. 452.

${ }^{164}$ Seymour Becker, Nobility and Privilege in Late Imperial Russia, DeKalb, 1985; M.J. Huggins, 'Thoroughbred Breeding in the North and East Ridings of Yorkshire in the Nineteenth Century', Agricultural History Review, 42, 1994, pp. 117-19.

165 PSZ, 2nd series, xl, no. 42426 (25 Aug. 1865); Dominic Lieven, The Aristocracy in Europe, 1815-1914, London, 1992, p. 44, table 2.6. 
handling the labour market and wrote penetratingly about it for Russkii vestnik. 'The English are right', Fet declared: 'time is money!' ${ }^{166}$ Some vendors acted equally rationally. One such was Count N.A. Orlov, who inherited Pady in 1861. Since Orlov's riding days were over once he lost an eye in the Crimea, it made sense to sell his best horses in France and Belgium when he moved to Brussels as ambassador in 1864; the remainder were auctioned at Pady. Other closures resulted from generational change. The president of the St Petersburg Medical Academy, P.A. Dubovitskii, continued to invest in the trotting stud he inherited and went on to take a leading role in the capital's elite racing circles. But when he died childless in 1868, the estate passed to his sister, who had no interest in horses, and the residence fell into desuetude. V.P. Okhotnikov's establishment in Voronezh province lasted longer. Indeed, it could still boast twenty-four stallions and ninety-three mares in 1882 when he sold it to the state. $^{167}$

In this newly commercialized world, the State Horse-breeding Board was lobbied by both advocates and opponents of state support. After his retirement, Grünewaldt claimed to have steered a moderate course, coaxing private breeders towards self-reliance but continuing to purchase English racehorses for the state. In 1872, the Board paid $£ 2,700$ for the 1862 Derby winner, Caractacus, a declining asset whose Russian stud career proved as mediocre as that of many of his predecessors. ${ }^{168} \mathrm{Had}$ his budget rivalled that of Prussia, Grünewaldt would have sent Russian horses to race in England, urged on by young journalists such as

\footnotetext{
${ }^{166}$ A.A. Fet to V.P. Botkin, 14/26 Sept. 1863, in A.A. Fet, p. 352; Fet, 'Iz derevni' in Sobranie sochinenii, ed. V.A. Koshelev et al., 20 vols, Moscow, 2004--, 4, pp. 121-388. On Fet's enthusiasm for stud-farming, see Tolstoy's Letters, ed. and trans. R.F. Christian, 2 vols, London, 1978, 1, p. 196 (16 May 1865).

${ }^{167}$ Materialy, pp. 107-13 (Orlov), pp. 3, 173-77 (Dubovitskii), pp. 240-42 (Okhotnikov); Zavod rysistykh loshadei statskago sovetnika Vasiliia Pavlovicha Okhotnikova, Voronezhskoi Gubernii, Zemlianskago Uezda, v sele Alekseevskom, Moscow, 1882.

${ }^{168}$ R. Grinval'd to I. Jessen (22 Aug. 1874), in Zamechaniia Professora Iessena o russkikh gosudarstvennykh konskikh zavodakh, n.p., n.d. [1878]), pp. 8-18; Sportsman, 3 Sept. 1872, p. 2.
} 
Samson Popov, who claimed that they were now no slower than English horses. ${ }^{169}$ But this ambition by no means reflected faith in speed alone. Utility was Grünewaldt's watchword. His aim, exemplified by the triennial all-Russian horse shows held at Moscow between 1866 and 1875, was, in Koptev's words, to 'destroy the false idea that the thoroughbred racehorse is in itself good for nothing, and should only be seen as a kind of adornment of other varieties'. Thoroughbreds had not only spawned the ideal riding horse in the past, but could generate more in the future if only races were to require stamina rather than agility: 'deeper conformations [and] shorter legs to carry heavier weights over longer distances', Koptev characteristically insisted, were preferable to 'sweeping jumps'. ${ }^{170}$

As Grünewaldt knew, many Russians doubted that the thoroughbred could transcend its natural fragility. Grand Duke Nikolai Nikolaevich's officers' races were for any breed except thoroughbreds. ${ }^{171}$ Nevertheless, the officers' races at Krasnoe Selo, re-instated in 1872, inspired the best-known contest in Russian literature. This was the three-mile steeplechase in Anna Karenina, whose author, immersed in the equestrian culture of Tula province, travelled to Orenburg while writing his novel to buy horses for a stud of his own. ${ }^{172}$ Watched by the tsar and a crowd of excited notables, Vronsky weighed in at a hefty elevenand-a-half stone, but while he was preparing to mount his beloved thoroughbred, Frou-Frou, a diminutive hussar flashed past to the start, 'crouching over his horse like a cat, in imitation of an English jockey'. Frou-Frou's trainer was the real thing - 'a lean Englishman in top boots and a short jacket' - and so was the highly-strung mare herself. Although 'not altogether free from reproach from a breeder's point of view' - her chest was narrow, her

\footnotetext{
${ }^{169}$ S.A. Popov, Skachki 1874 goda, Moscow, 1875, pp. 53-55.

${ }^{170}$ On national shows, see Materialy, pp. 443-564, esp. pp. 477-78, original emphasis. Provincial shows were listed in the Board's annual Pamiatnye knizhki.

${ }^{171}$ PSZ, 2nd series, xlii, no. 44223 (9 Feb. 1867).

${ }^{172}$ L.N. Tolstoi to S.A. Tolstaia, 4, 5, 17 Sept. 1876, in L.N. Tolstoi, Polnoe sobranie sochinenii, ed. V.G. Chertkov et al., 90 vols, Moscow, 1929-64, 83, pp. 226, 228, 232.
} 
legs bowed and her trunk out of proportion - Frou-Frou 'possessed in the highest degree that quality that made one forget her defects: that quality was blood, the blood that tells, as the English expression has it'. ${ }^{173}$

\section{Into the era of mass entertainment}

We should pause before accepting that Vronsky's race represented a fading aristocratic culture, soon eclipsed in an era of mass entertainment subsidized by legalized mass betting. ${ }^{174}$ The mid-1870s certainly marked a caesura in the history of Russian horse-racing. Though I.P. Petrovskii won a medal at the 1872 All-Russian Horse Show, most founding-members of the Lebedian racing society were dead, and a new generation of breeders carried the sport into the age of the tote, guided by advice literature covering management techniques for the specialist labour-force their studs now required. ${ }^{175}$ Even that literature became rapidly outdated once Russia experienced the 'American revolution' that simultaneously transformed the English turf, and in Russia affected both thoroughbred- and harness-racing. ${ }^{176}$ On racedays, cultural differences between the two became blurred as both thoroughbreds and trotters competed before unprecedentedly large crowds whose gambling subsidized elaborate pavilions at hippodromes linked by an expanding railway network. These features have sustained horse-racing's reputation as Russia's first national sport.

Without betting, however, Russian horse-racing, like its English counterpart, 'would have been no more national than 12-metre yachting or deer-hunting' ${ }^{177}$ Behind the scenes, much of the old equestrian culture survived into the twentieth century, sustained, as

\footnotetext{
${ }^{173}$ Leo Tolstoy, Anna Karenin, trans. Rosemary Edmonds, Harmondsworth, 1978, pp. 213, 198-99.

${ }^{174}$ McReynolds, Russia at Play, p. 79.

175 N. Tikhomirov, Rysak: ego vyderzhka, vyezdka i podgotovka na priz, 2nd edn, Moscow, 1879, pp. 164-76.

176 Vamplew, The Turf, pp. 49-61.

${ }^{177}$ Ross McKibbin, Classes and Cultures: England 1918-1951, Oxford, 1998, p. 353.
} 
elsewhere in Europe, by the persistence of aristocratic values in the cavalry. ${ }^{178}$

Thoroughbreds remained indelibly associated with England; the Russo-Turkish War of 1877-

78 fuelled renewed debate on their military capabilities; the chronicler of the Krasnoe Selo races, Colonel Kronid Agafonov (b. 1859), defended the breed and criticized the tote in the veterans' official newspaper, Russkii invalid; and the issue was still live at the first national congress of horse-breeders, held at Moscow's hall of the nobility in $1910 .{ }^{179}$ Both thoroughbred- and harness-racing remained pastimes for the rich, and even if the moneyed classes now ranged beyond the aristocracy, the old world still ruled. Grand Duke Dmitrii Pavlovich rode an Irish horse for Russia in the equestrian events introduced for cavalrymen at the 1912 Stockholm Olympics. ${ }^{180}$ Prince Dmitry Soltykoff, the first Russian to be elected to the Jockey Club in 1867, founded the Kremlin Lodge stud, still thriving at Newmarket, and befriended the future King Edward VII. ${ }^{181}$ There was no necessary contradiction in the coalescence at the races of royalty, aristocracy, new money and the masses: the British monarchy's enthusiasm for horse-racing has enhanced the popularity of both. ${ }^{182}$ Russian grand dukes were not so lucky. But the elusive quest for the perfect cavalry horse continued

178 Tony Mason and Eliza Riedi, Sport and the Military: The British Armed Forces, 18801960, Cambridge, 2010, ch. 2.

${ }^{179}$ [General A. Strukov] Chistokrovnaia angliiskaia loshad'v stroiu i v pokhode: (Iz opyta minuvshei voiny), Moscow, 1879; [K.A. Diterikhs], Proizvodstvo iskomoi nyne kaveleriiskoi loshadi: Po povodu st. g. Strukova 'Chistokrovnaia angliiskaia loshad'v stroiu i v pokhode', St Petersburg, 1881; [A. Strukov], K voprosu o sluzhebnykh dostoinstvakh angliiskoi chistokrovnoi loshadi, [St Petersburg], 1883; K. Agafonov, Krasnosel'skie skachki: ocherk (1872-1880 gg.), 2 vols, St Petersburg, 1898-99; I.M. Il'enko, 'Znachenie chistokrovnoi angliiskoi loshadi i ispytanii dlia zavodskogo materiala': Vserossiiskii s"ezd konnozavodchikov 1910 g. v Moskve, Moscow, 1910.

${ }^{180}$ Erik Bergvall (ed.), The Fifth Olympiad: The Official Report of the Olympic Games of Stockholm 1912, trans. Edward Adams-Ray, Stockholm, 1913, pp. 504-615, esp. pp. 597, 600, and plates, pp. 592-93.

181 Thormanby, Kings of the Turf: Memoirs and Anecdotes of Distinguished Owners, Backers, Trainers and Jockeys, London, 1898, pp. 300-3; The Times, 23 Nov. 1903, p. 6, obituary.

${ }^{182}$ Conceived in response to McKibbin (above, n. 177), the excellent Mike Huggins, Horseracing and the British 1919-39, Manchester, 2003, oddly makes no mention of the monarchy. 
under the Bolsheviks, for whom Marshal Budennyi developed his eponymous cross-breed, sired by the sort of handsome thoroughbred that Stalin presented to Averell Harriman. ${ }^{183}$

${ }^{183}$ Gosudarstvennaia plemennaia kniga chistokrovnykh (angliiskikh) loshadei, MoscowLeningrad, 1935. 